\title{
An Extensive Phase Space for the Potential Martian Biosphere
}

\author{
Eriita G. Jones, ${ }^{1}$ Charles H. Lineweaver, and Jonathan D. Clarke ${ }^{2}$
}

\begin{abstract}
We present a comprehensive model of martian pressure-temperature (P-T) phase space and compare it with that of Earth. Martian P-T conditions compatible with liquid water extend to a depth of $\sim 310 \mathrm{~km}$. We use our phase space model of Mars and of terrestrial life to estimate the depths and extent of the water on Mars that is habitable for terrestrial life. We find an extensive overlap between inhabited terrestrial phase space and martian phase space. The lower martian surface temperatures and shallower martian geotherm suggest that, if there is a hot deep biosphere on Mars, it could extend 7 times deeper than the $\sim 5 \mathrm{~km}$ depth of the hot deep terrestrial biosphere in the crust inhabited by hyperthermophilic chemolithotrophs. This corresponds to $\sim 3.2 \%$ of the volume of present-day Mars being potentially habitable for terrestrial-like life. Key Words: Biosphere-MarsLimits of life-Extremophiles-Water. Astrobiology 11, 1017-1033.
\end{abstract}

\section{Introduction}

$\mathbf{N}$ ASA'S "FOLLOW THE WATER" strategy for Mars exploration is based on the observation that all terrestrial life requires liquid water during some phase of its life cycle (Hubbard et al., 2002). Thus, our increasingly detailed knowledge of the abundance and phases of $\mathrm{H}_{2} \mathrm{O}$ on Mars may be our best guide in our search for life on Mars (Haberle et al., 2001; Jakosky et al., 2005a, 2005b, Heldmann et al., 2007; Milliken et al., 2007; Renno et al., 2009; Möhlmann, 2010a). However, not all liquid water on Earth is habitable. Jones and Lineweaver (2010) showed that $88 \%$ of the volume of Earth where liquid water could exist is not known to harbor life. Pressure and temperature allow liquid water on Earth to a maximum depth of $\sim 75 \mathrm{~km}$. Our search for life on Mars can be informed by our knowledge of inhabited and uninhabited terrestrial water.

From our current state of knowledge, the limiting factors for terrestrial life can be summarized as (i) temperatures above $\sim 122^{\circ} \mathrm{C}$ (Kashefi and Lovley, 2003; Takai et al., 2008); (ii) low water activity with $a_{\mathrm{w}}<0.6$ (Grant, 2004; however, there may be the potential for active life in lower water activities as reported by Schulze-Makuch et al., 2011); and (iii) a combination of lack of nutrients and low water activity with temperatures below $-20^{\circ} \mathrm{C}$, the current minimum temperature for active life (Junge et al., 2004). The latter occurs in permafrost, arctic climates, and at altitudes above $10 \mathrm{~km}$.
The apparent high-pressure limit to life beneath oceanic and continental crust seems to be a limit of observations, not of life (Jones and Lineweaver, 2010). There is theoretical discussion that liquids other than water could support different forms of life with unique biochemistries (Irwin and Schulze-Makuch, 2001; Bains, 2004; Benner et al., 2004; Schulze-Makuch and Irwin, 2006). For the purposes of this study, however, we have assumed that liquid $\mathrm{H}_{2} \mathrm{O}$ is the most plausible life-sustaining fluid for Mars.

In the present study, we developed a pressure-temperature (P-T) model of Mars and compared it to the P-T diagram of water to quantify the maximum possible extent of liquid water on Mars. We then superimposed the P-T conditions that are hospitable to terrestrial life to identify the potential liquid water environments on Mars that would be able to support terrestrial life. We also examined the large range in soil temperatures consistent with the shallow equatorial martian subsurface and the likelihood of liquid water in such environments.

\section{The Pressure-Temperature Phase Diagram of Mars}

In Fig. 1, martian environments, estimated from surface measurements (Table 1), modeled subsurface geotherms, and atmospheric lapse rate (see Table A1, Appendix A) are compared with the phase diagram of two types of liquid water relevant to Mars. Figure 1 shows regions of phase space where martian environments have the potential to

\footnotetext{
${ }^{1}$ Planetary Sciences Institute, Research School of Astronomy and Astrophysics and the Research School of Earth Sciences, Australian National University, Canberra, Australia.

${ }^{2}$ Mars Society Australia, Inc., Canberra, Australia.
} 


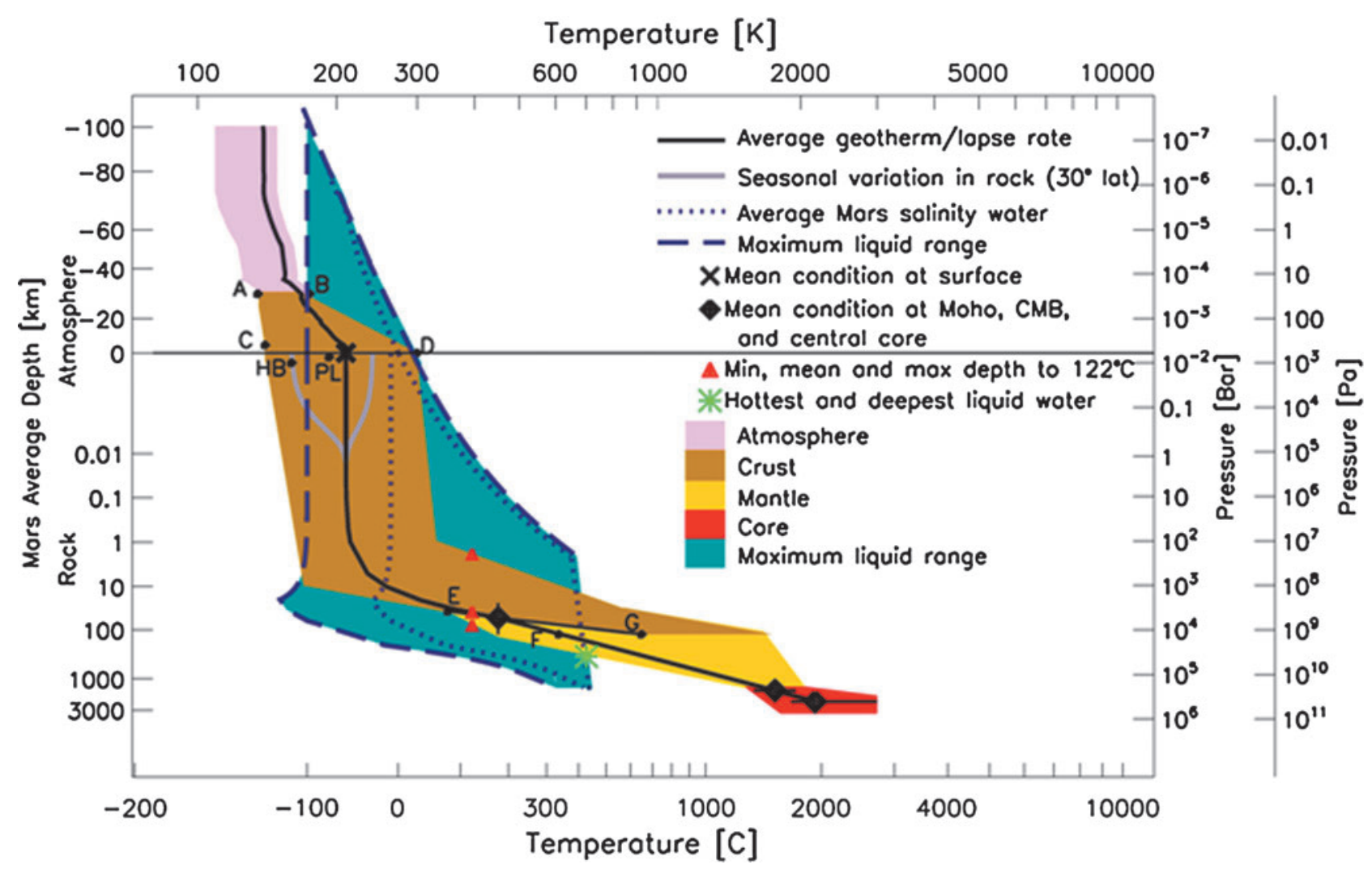

FIG. 1. Mars and liquid water. Superposition of martian environments on the P-T diagram of two versions of martian water. "Average Mars salinity water" has a freezing point of $-10^{\circ} \mathrm{C}$, while "Maximum liquid range" has a freezing point of $-100^{\circ} \mathrm{C}$, and its phase space is shaded in blue. Mars' core, mantle, crust and atmosphere are colored separately. The geophysical model used to construct the P-T range of martian environments is described in Appendix A. Subsurface seasonal temperature variations in rock at absolute latitude $30^{\circ}$ are shown (gray curves, see also Fig. 4 and Appendix C). The horizontal thin line at 0.006 bar is the average atmospheric pressure of Mars. The black cross on that line marks the average surface temperature, $-63^{\circ} \mathrm{C}(210 \mathrm{~K})$. Letters indicate the extreme P-T values listed in Table 1. For example, A and B represent the coldest and hottest days on the summit of Olympus Mons. HB and PL indicate the P-T conditions at Hellas Basin and the Phoenix lander, respectively. The black diamonds give the mean modeled conditions at the crust-mantle boundary (Moho), core-mantle boundary (CMB), and the center of the core (Tables 1 and A1). The green asterisk represents our estimate of the hottest and deepest possible liquid water on Mars at $T \sim 427^{\circ} \mathrm{C}$ and $P \sim 4 \times 10^{4}$ bar, corresponding to a depth of $\sim 310 \mathrm{~km}$. The red triangles indicate the intersection of the average martian geotherm and the minimum and maximum boundaries of phase space with $122^{\circ} \mathrm{C}$.

contain liquid water. For example, it shows regions where there is Mars but no liquid water and where there could be liquid water (blue shading) but there is no Mars.

"Average Mars salinity water" freezes at $-10^{\circ} \mathrm{C}$ at the triple point and provides an estimate of the phase space of a likely martian brine that contains magnesium, iron, and calcium sulfates (Jagoutz, 2006; Tosca et al., 2008) at 0.4-8\% wt (Bibring et al., 2005; Gendrin et al., 2005; Yen et al., 2005; Marion et al., 2010); magnesium and iron carbonates (Tosca et al., 2008); and sodium chloride (total amount of salts in soil $<10 \mathrm{~mol} / \mathrm{kg}$; Marion et al., 2009). Results from Mars Odyssey indicate that in some locations the fraction of magnesium sulfate salts in the soil may reach $30 \% \mathrm{wt}$ (Vaniman et al., 2004).

The "Maximum liquid range" is appropriate for the potentially concentrated briny inclusions and thin liquid films in ice and permafrost (Price, 2000; Davis, 2001; Möhlmann, 2008) beneath the martian surface ( $c f$. Jones and Lineweaver, 2010, for Earth water). It has a freezing point depression of $-100^{\circ} \mathrm{C}$ (Pearson and Derbyshire, 1974) at the triple point and is an estimate of the coldest possible liquid water on Mars (see Jones and Lineweaver, 2011). The details of our Mars model, including estimates of uncertainties and how the core (red), mantle (yellow), crust (light brown), and atmosphere (pink) were constructed, are described in Appendix A.

The phase space of terrestrial life is shown in Fig. 2 superimposed on the P-T diagram of Earth and of Mars. The current high-temperature limit for terrestrial life is $\sim 122^{\circ} \mathrm{C}$ (Kashefi and Lovley, 2003; Takai et al., 2008). The current low-temperature limit for active life is $\sim-20^{\circ} \mathrm{C}$ (Junge et al., 2004) and might be more correctly understood as a limit due to low water activity (Grant, 2004; Tosca et al., 2008; Jones and Lineweaver, 2011). The low mean geothermal gradient in the martian crust $(\sim 5 \mathrm{~K} / \mathrm{km}$ compared to $\sim 25 \mathrm{~K} / \mathrm{km}$ on Earth) and its variation (shown by the width of the phase model at a given depth) provide deep, cool environments not found on Earth (down to 10s of kilometers on Mars) that may be suitable for life (Pedersen, 2000; Chivian et al., 2008; Sherwood Lollar et al., 2009). Although there are empirical high- and low-pressure limits for terrestrial life, these are 
Table 1. Extreme and Reference Point Temperatures and Pressures on Mars' Surface, Crust, and Mantle

\begin{tabular}{|c|c|c|c|c|}
\hline Key & Environment & $\begin{array}{l}\text { Pressure (bar) } \\
\text { Depth }(\mathrm{km})\end{array}$ & $\operatorname{Temp}\left({ }^{\circ} \mathrm{C}\right)$ & Reference \\
\hline A, B & Olympus Mons summit & $\begin{array}{l}25 \times 10^{-4} \\
-27\end{array}$ & -138 to -96 & Hinson et al., 2004 \\
\hline $\mathrm{C}$ & $\begin{array}{l}\text { Minimum surface temperature } \\
\text { (south pole ice cap) }\end{array}$ & $\begin{array}{l}3.9 \times 10^{-3} \\
-5\end{array}$ & -133 & Kieffer et al., 1977; Carr, 2006 \\
\hline $\mathrm{D}^{*}$ & $\begin{array}{l}\text { Maximum surface temperature } \\
\text { (Opportunity landing site, } \\
\text { Meridiani Planum, } 3 \mathrm{~km}^{*} \text { ) }\end{array}$ & $\begin{array}{c}3.9 \times 10^{-3} \\
0\end{array}$ & 30 & Smith et al., 2006; Carr, 2006 \\
\hline $\mathrm{E}^{\dagger}$ & $\begin{array}{l}\text { Shallow, cold Mohorovicic } \\
\text { discontinuity at base of crust }\end{array}$ & $\begin{array}{c}3.8 \times 10^{3} \\
35\end{array}$ & 77 & $\begin{array}{l}\text { Zuber et al., 2000; Wieczorek and } \\
\text { Zuber, } 2004\end{array}$ \\
\hline $\mathrm{F}$ & Deep, Mohorovicic discontinuity & $\begin{array}{l}1.2 \times 10^{4} \\
100\end{array}$ & 377 & $\begin{array}{l}\text { McGovern et al., 2002; Wieczorek } \\
\text { and Zuber, 2004; Sohl et al., } 2005\end{array}$ \\
\hline $\mathrm{G}^{\dagger}$ & $\begin{array}{l}\text { Plausible maximum temperature of } \\
\text { Mohorovicic discontinuity }\end{array}$ & $\begin{array}{l}1.2 \times 10^{4} \\
100\end{array}$ & 650 & $\begin{array}{l}\text { McGovern et al., 2002; Zuber et al., } \\
\text { 2000; Sohl et al., 2005 }\end{array}$ \\
\hline HB & $\begin{array}{l}\text { Lowest point on surface, maximum } \\
\left.\text { surface pressure (Hellas Basin, } 29^{\circ} \mathrm{S}\right)\end{array}$ & $\begin{array}{c}(0.9-1.02) \times 10^{-2} \\
8.2\end{array}$ & -123 to -70 & Hinson et al., 2004 \\
\hline PL & $\begin{array}{l}\text { Northern arctic in late spring/early } \\
\text { summer (Phoenix landing site) }\end{array}$ & $\begin{array}{c}7.5 \times 10^{-3} \\
2\end{array}$ & -80 & Nelli et al., 2009 \\
\hline
\end{tabular}

*Due to the lack of low latitude zero-elevation temperature measurements, we take the measurement made by the Opportunity rover at 3 $\mathrm{km}$ below the zero-elevation surface as the maximum surface temperature at zero elevation.

"The majority of the geotherms used to construct the shaded crust region were "hot models" that are now less favored in the literature (see instead the references in Table 1 and Fig. 1). Thus although the Mars phase space incorporates both older and more recent models, the letters in Table 1 highlight our estimates of the most plausible extreme temperatures and pressures. Hence E appears near the boundary of the shaded region, and $\mathrm{G}$ is not at the maximum temperature of the phase space at its particular pressure.

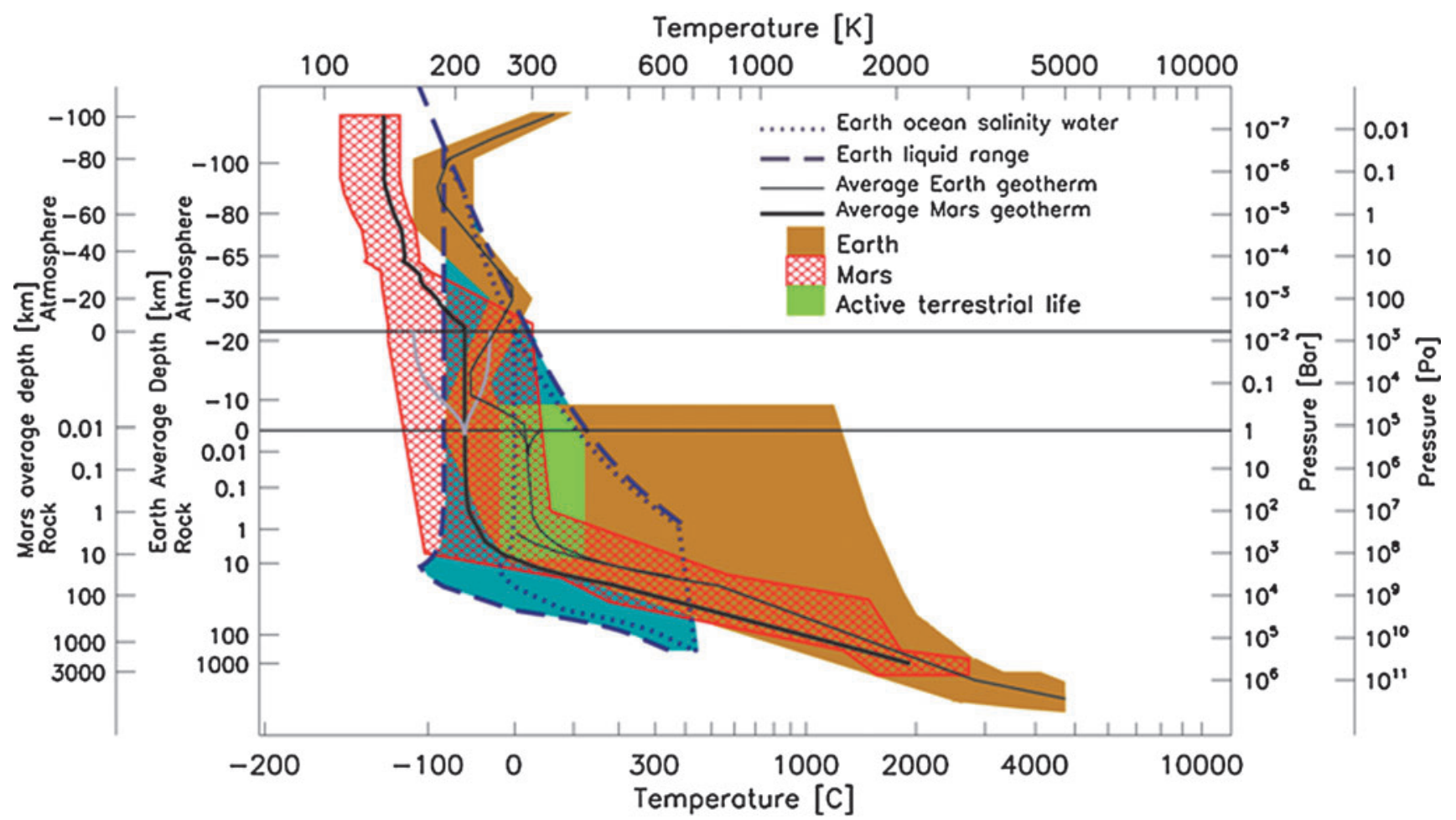

FIG. 2. Mars, Earth, water, life. Superposition of four phase regions showing the extensive overlap of Mars with the inhabited regions of Earth. The Mars region is from Fig. 1. The Earth (brown), life (green), and water (blue) regions are taken from Fig. 5 in Jones and Lineweaver (2010). The mean geotherms through Earth (thin black line) and Mars (thick black line) are shown. Shallow mantle intrusions on Earth provide shallow, hot environments not found on Mars due to its low presentday geological activity. The annual subsubsurface temperature profile for martian rock at $\sim 30^{\circ}$ absolute latitude is reproduced from Fig. 1 (gray curves). For comparison, an estimated terrestrial subsurface profile of seasonal temperature variation is also shown. The martian seasonal temperature variations penetrate deeper (skin depth of $3 \mathrm{~m}$ compared to $2.2 \mathrm{~m}$ for Earth rock) because of the larger winter-summer temperature difference and the longer martian year. As the maximum and minimum soil temperatures within a year are not equidistant from the average soil temperature, both shallow temperature profiles are asymmetric around the average. 


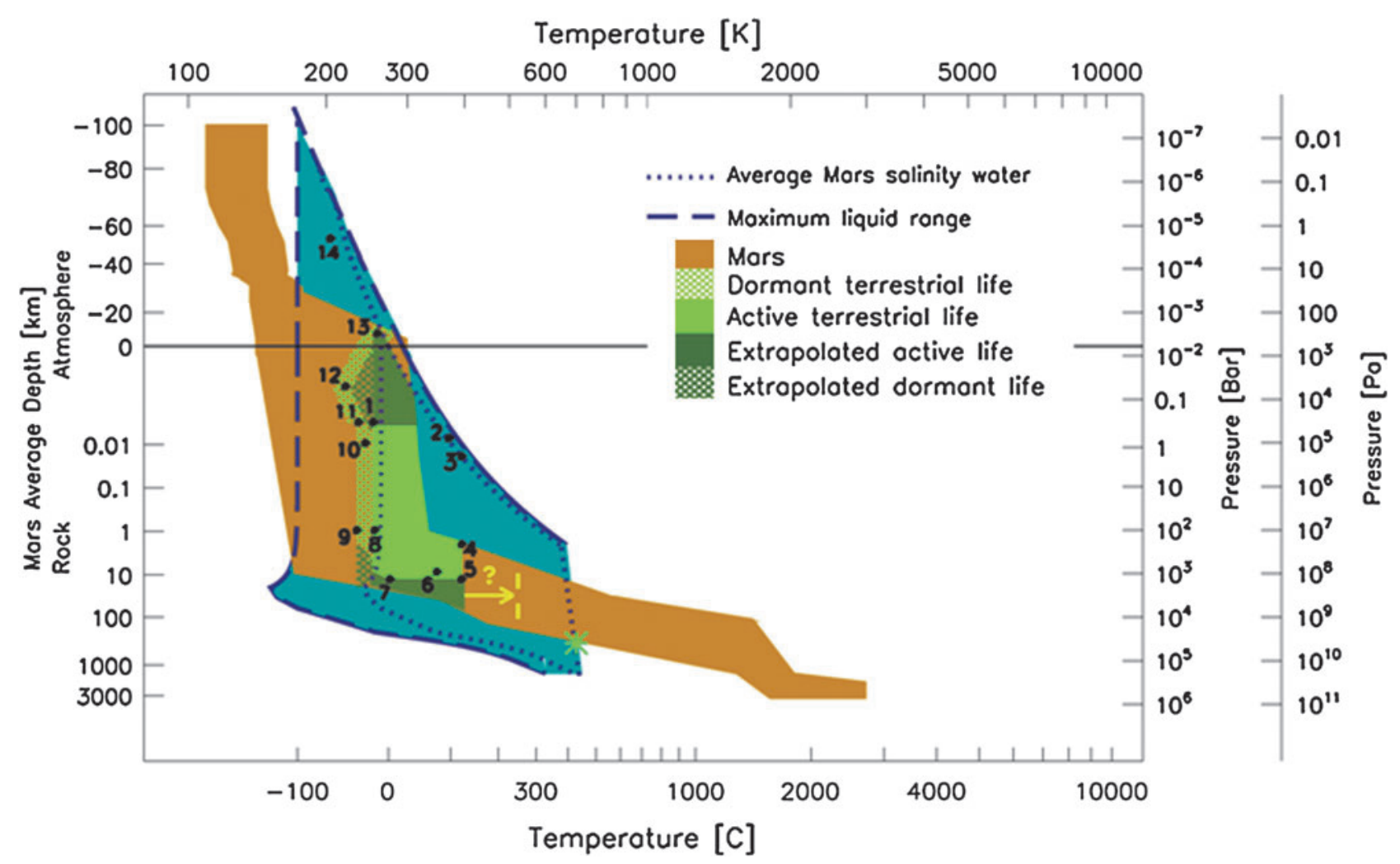

FIG. 3. Phase model of the potential martian biosphere. For clarity, only the overlap of the light green "Active life" region from Fig. 2 with actual martian environments is shown. This light green region extends from a few meters to $\sim 10 \mathrm{~km}$ depth in the warmest subsurface regions of Mars. We assume $T_{\max }=122^{\circ} \mathrm{C}$ is the maximum temperature compatible with life. Since apparent pressure constraints on terrestrial life are probably not fundamental, we have extrapolated the "Active life" region to higher and lower pressures (dark green). This widens the potential biosphere of Mars to the warmest briny water in the near subsurface and to a depth of $\sim 36 \mathrm{~km}$. Numbers 1-8 in Fig. 3 circumscribe our estimate of the region occupied by active terrestrial life and are described in Table B1 in Appendix B (reproduced from Table 3 in Jones and Lineweaver, 2010). Some warm, $\sim 1$ bar terrestrial environments do not exist in martian phase space, such as numbers $2-3$. Numbers 9-14 and the light green area represent our estimate of the region occupied by dormant terrestrial life and are described in Table B2 (reproduced from Table 4 in Jones and Lineweaver, 2010). The question mark and the yellow arrow pointing from the current upper temperature limit of life $\left(T_{\text {life }}<122^{\circ} \mathrm{C}\right)$ to the vertical dashed yellow line at $T=250^{\circ} \mathrm{C}$ represent the additional phase space of the biosphere if terrestrial life can extend to $T=250^{\circ} \mathrm{C}$.

probably due to limited sampling rather than to fundamental limits of biochemistry (Jones and Lineweaver, 2010 and references therein). Figure 3 shows an extrapolation of the "Active life" and "Dormant life" regions to higher pressures. This is justified since the apparent high-pressure limit to life beneath oceanic and continental crust seems to be a limit of observations, not of life (Jones and Lineweaver, 2010). Active terrestrial life is limited to pressures above 0.3 bar; however, the limiting factor is more likely to be a lack of nutrients and water at high altitudes rather than pressure (Jones and Lineweaver, 2010). Thus, it is plausible that life on Mars could inhabit subsurface environments at low pressures $<0.3$ bar, provided that the temperature is above $-20^{\circ} \mathrm{C}$ and liquid water is available with a high-enough water activity, and that life has a source of energy and nutrients. Some highaltitude dormant life conditions on Earth are reached in the shallow subsurface of Mars. Thus, we extrapolate the active and dormant life regions to both lower and higher pressures (still within the martian subsurface).

From Fig. 1, the maximum possible depth of liquid water on Mars (at temperatures of $\sim 427^{\circ} \mathrm{C}$ ) is $\sim 310 \mathrm{~km}$, as it is the highest-pressure environment in the martian P-T space along the critical water line. The maximal possible extent of liquid water on Mars-from the surface to $\sim 310 \mathrm{~km}$ depthindicates that, at most, $\sim 25 \%$ of the volume of Mars could support liquid water.

Comparing the martian phase space with that of active (Figs. 2 and 3) and dormant (Fig. 3) life shows extensive overlap. The maximum depth of the potential biosphere is determined by the depth at which temperatures exceed $122^{\circ} \mathrm{C}$ within the phase space of "average Mars salinity water." From the mean geotherm in Fig. 1, temperatures of $122^{\circ} \mathrm{C}$ occur at a mean depth of $\sim 36 \mathrm{~km}$ (middle red triangle in Fig. 1). From the height of the shaded region of the martian phase space around this mean geotherm, temperatures of $122^{\circ} \mathrm{C}$ may occur as shallow as $\sim 6 \mathrm{~km}$ and as deep as $\sim 50 \mathrm{~km}$ (upper and lower red triangles in Fig. 1). This range of $\sim 6-50 \mathrm{~km}$ will be constrained as the deep geothermal gradients in Mars become known. Taking a mean depth of $\sim 36 \mathrm{~km}$ for the maximum extent of the potential biosphere of Mars, the potential biosphere could then occupy a shell of $\sim 3.2 \%$ of the volume of Mars. Considering that liquid water on Mars can extend to, at most, $\sim 310 \mathrm{~km}$ deep (Fig. 1), the potential biosphere corresponds to $\sim 31 \%$ of the volume of 


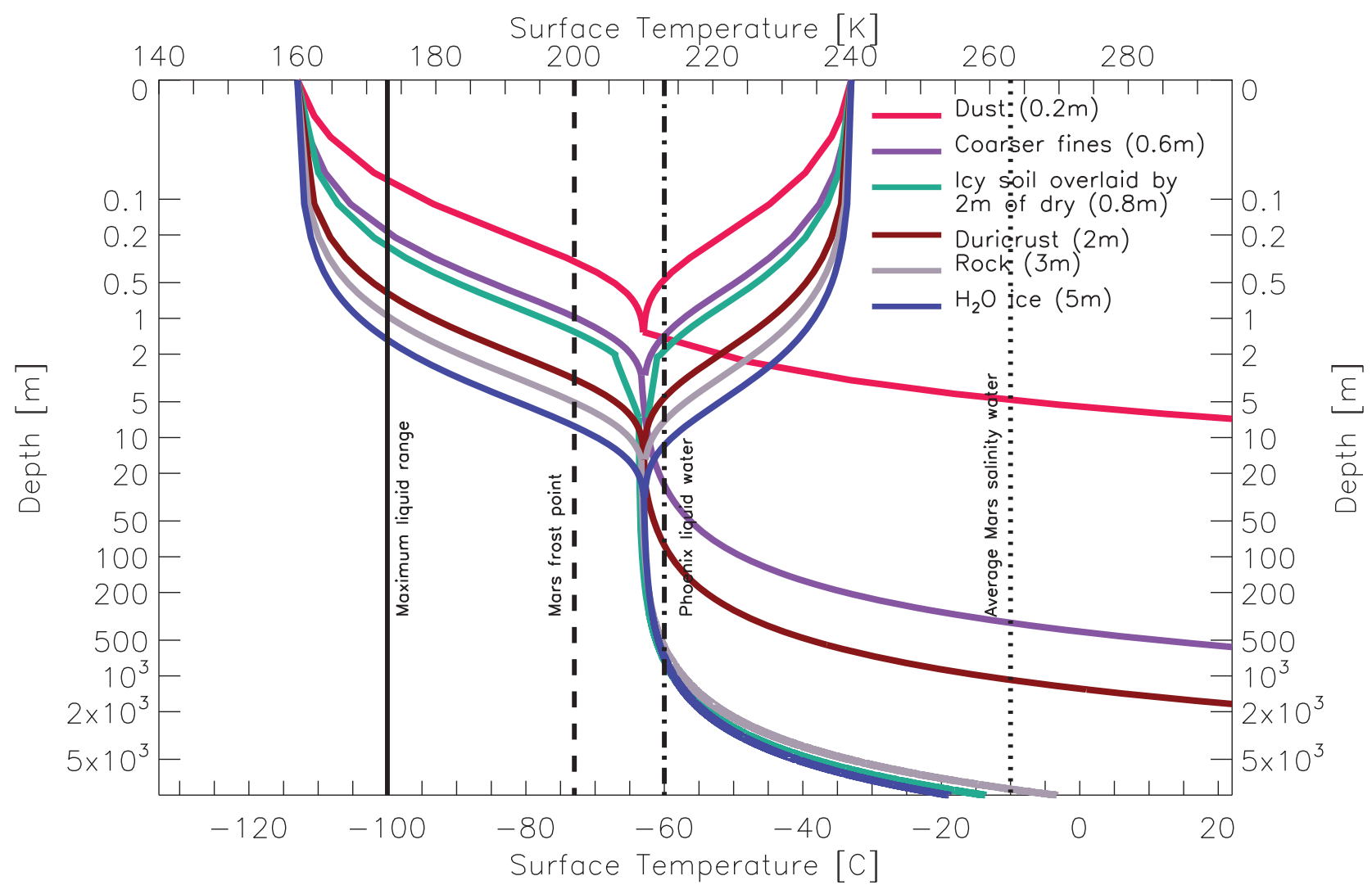

FIG. 4. Estimated maximum range in subsurface temperatures during a martian year at $\sim 30^{\circ}$ absolute latitude. The freezing temperatures of average Mars salinity water $\left(\right.$ at $-10^{\circ} \mathrm{C}$ ) and maximum liquid range (at $\left.-100^{\circ} \mathrm{C}\right)$ are shown. The thermal skin depth (depth at which temperature fluctuations drop to 1/e of their surface value) is shown in brackets for each material. Below this depth, the geothermal gradient dominates subsurface temperatures and is determined by the ratio of the heat flow to the thermal conductivity of the material. Fines and duricrust have low thermal conductivities and so have large temperature gradients. Details are given in Appendix C.

Mars with liquid water that may support life. In other words, at least $\sim 69 \%$ of the volume of Mars where liquid water could exist cannot support life, given our current best geothermal models. If life can survive temperatures of $250^{\circ} \mathrm{C}$ (e.g., in terrestrial hydrothermal vents, Martin et al., 2008), then the martian biosphere could extend to $\sim 61 \mathrm{~km}$ from the average geotherm in Fig. 1 . At a depth of $\sim 7 \mathrm{~km}$, the average Mars geotherm in Fig. 1 reaches the minimum temperature of active terrestrial life of $-20^{\circ} \mathrm{C}$. If water ice is present at these depths and there is sufficient pore space, liquid water can be expected as thin films or brine lenses.

Figure 4 presents an estimate for the annual range in shallow subsurface temperatures in a range of materials on present-day Mars. The potential biosphere of Mars (all the green shading in Fig. 3) extends from the surface in locations such as Hellas, Argyre, and absolute latitudes $<30^{\circ}$ where the partial pressures and temperatures allow water to be a liquid for several days during a martian year (Haberle et al., 2001), which makes the shallow soil potentially habitable (Wang et al., 2010). Figure 4 shows that the subsurface temperatures at equatorial latitudes are unlikely to become warm enough for life shallower than $\sim 5 \mathrm{~m}$ depth. At depths $>5 \mathrm{~m}$, the temperature may be $>-20^{\circ} \mathrm{C}$ in fines and dust. Generally, for liquid water to occur at these shallow depths it will be either a thin film coating grains or an extremely briny liquid within the pore space (e.g., liquid with a freezing temperature of $-40^{\circ} \mathrm{C}$ could occur in the top $50 \mathrm{~cm}$ of coarse fines). The theoretical presence of liquid water in the "icy soil" of Fig. 4 on a diurnal and seasonal timeframe is supported by modeling results of Möhlmann (2010b).

\section{Discussion}

Studies of terrestrial organisms have shown that some psychrophiles show high survival rates in environments analogous to the martian surface and shallow subsurface. Studies of methanogens from Siberian permafrost in simulated pressure, temperature, atmospheric composition, and water vapor conditions of the martian surface in the midlatitudes found a 90\% survival rate (Morozov et al., 2007). The methanogens utilized liquid water in the soil from adsorbed water vapor with a variable activity between 0.1 and 0.9. This study shows that the adaptations of microbes to survive in permafrost are well suited to the large diurnal variations in temperatures and water activity consistent with the shallow martian subsurface.

Figure 3 shows that there are environments in the subsurface of Mars that have pressure and temperature conditions that are hospitable to terrestrial life. There are also environments that may be hospitable to terrestrial life if we extrapolate to pressures outside the range where active life has been found in terrestrial environments, but remain 
within the range of Mars salinity water and temperatures between $-20^{\circ} \mathrm{C}$ and $122^{\circ} \mathrm{C}$ (dark green regions).

\subsection{Liquid water phase model}

Figures 2 and 3 reveal that the potential martian biosphere (P-T conditions that allow for liquid water and are within both the phase space of active terrestrial life and the P-T conditions of Mars) may potentially be encountered at $5 \mathrm{~m}$ beneath the martian subsurface in equatorial latitudes (see Fig. 4). If liquid water is present over this depth range, it may be exposed to the atmospheric pressure, which would cause it to vaporize quickly. The shallow subsurface pressure gradient on Mars varies spatially due to variations in both overburden pressure and soil closure. Terrestrial soil can be permeable to the atmosphere for tens of centimeters before a sealing agent (e.g., salt) or an impermeable strata is encountered (e.g., Heard et al., 1988). On Mars, the situation may be similar. Freezing conditions can also cement soil together, and the abundance of very fine-grained particulates on Mars (dust) can effectively fill the pore spaces in the regolith (Hudson and Aharonson, 2008). It is, however, possible that the subsurface is permeable to the atmosphere through the top $\sim 10 \mathrm{~m}$ in regolith and rock. In this situation, any liquid water in the top $\sim 10 \mathrm{~m}$ would not be stable and would be lost to the atmosphere, with the rate of vaporization depending on the relative humidity (Sears and Moore, 2005) and water activity (Altheide et al., 2009).

At temperatures below $0^{\circ} \mathrm{C}$, liquid water can exist as either a thin film or a brine with a freezing point $<0^{\circ} \mathrm{C}$. Including salts to estimate "average Mars salinity water" expands the regions where liquid water can occur. Modeling by Mellon and Phillips (2001) showed that a concentration of $15-40 \%$ of salts (sulfates, chlorides, bromides, carbonates, and nitrates) is sufficient to allow the melting of ground ice (or to maintain liquid water) in the top few meters of soil. Furthermore, Hecht (2002) concluded that it is possible for pure liquid water to form from ice-melt in shallow Sun-facing slopes at absolute latitudes $\geq 60^{\circ}$, in environments similar to the alcove bases of many martian gullies (Heldmann and Mellon, 2004; Heldmann et al., 2007). These results are similar to models by Marquez et al. (2005) and Christensen (2003), which showed that icy materials apparently connected with some gullies may generate shallow liquid water from solar heating within the top $\sim 20 \mathrm{~cm}$ of the subsurface. Deeper liquid water, $>200 \mathrm{~m}$ below the martian surface, may be stable beneath dry, unconsolidated regolith with a low conductivity and a geothermal heat flux of $30 \mathrm{~mW} / \mathrm{m}^{2}$ (Mellon and Phillips, 2001). This depth is consistent with the global average depth of the alcove bases of martian gullies. Gully alcove bases, indicative of the depth of the source fluid, vary between the surface to $2 \mathrm{~km}$ beneath the upper land surface at absolute latitudes $\geq 30^{\circ}$ (Heldmann and Mellon, 2004; Heldmann et al., 2007).

The activity of subzero liquid water may be an important factor in whether it can be utilized by biology. The activity is defined as the ratio of the vapor pressure over supercooled liquid water (Koop, 2004) to the vapor pressure over ice (Schulze-Makuch and Irwin, 2008). The activity of supercooled liquid water is 0.82 at $-20^{\circ} \mathrm{C}, 0.67$ at $-40^{\circ} \mathrm{C}$, and 0.6 at $-50^{\circ} \mathrm{C}$ (see Table 5 in Fennema, 1996, and references therein). In the presence of an ice phase (i.e., at temperatures below $0^{\circ} \mathrm{C}$ ), the activity becomes independent of solutes and only depends on temperature (Koop et al., 2000). Möhlmann (2005) showed that $a_{\mathrm{w}}$ of a thin film drops below 0.6 when the film is less than 3 water molecules thick, which occurs at temperatures less than $\sim-20^{\circ} \mathrm{C}$ (Anderson and Tice, 1972; Jakosky et al., 2003). The decrease of activity of the film with further decreasing temperatures is not well known. A martian brine may have a freezing point anywhere between $-10^{\circ} \mathrm{C}$ to $-60^{\circ} \mathrm{C}$, depending on which sulfate and chloride salts are present (Jagoutz, 2006; Chevrier and Altheide, 2008; Tosca et al., 2008; Chevrier et al., 2009; Marion et al., 2009) and on their relative ratios in solution. The water activity of brines decreases sharply with decreasing temperatures below zero (Morillon et al., 1999); however, the analytical relationship for each salt is not known. Magnesium and calcium chloride and magnesium sulfate have activity $<0.35$ at subzero temperatures (Table 1 in Jones and Lineweaver, 2011, and references therein), so they are not good candidates to support life. Salts such as magnesium nitrate and sodium bromide may also be able to support terrestrial life at temperatures as low as $-30^{\circ} \mathrm{C}$ as the $a_{\mathrm{w}}$ of the solution remains above 0.6; however, these salts may not be present on Mars (Jones and Lineweaver, 2011).

\subsection{Pore space}

Despite subsurface P-T conditions that allow water to be liquid, the existence of liquid water and life will depend on the availability of pore space. The maximum porosity at a given depth decreases with increasing depth as pore space becomes more restricted (Athy, 1930). Life may have a minimum pore space requirement; however, it is likely that the connectedness of pore space, which governs the flow of fluid, is more fundamental. On Mars, a minimum threshold for pore space would be achieved at a greater depth than on Earth given the lower overburden pressure (Mars has $~ 1 / 3$ of Earth's surface gravity). Pore space deforms at high temperatures of $\sim 400^{\circ} \mathrm{C}$ (Hyndman and Shearer, 1989, and references therein); hence, rocks that have experienced depths of $\sim 200 \mathrm{~km}$ on Mars would be expected to have no pore space (however, overburden pressure in combination with the low yield strength of rocks due to high temperature may effectively close pore space before these temperatures are reached). The closure depth of pore space for any particular rock type is poorly known; however, pore space in martian plutonic rocks would be expected to fall below 1\% volume at depths greater than $40 \mathrm{~km}$ (less deep for basalts), which corresponds to $\sim 350 \mathrm{MPa}$ (Abdulagatov et al., 2006). Appendix D provides a more detailed discussion of the dependence of pore space on depth.

The flow of fluid through material is controlled by its permeability-determined by the connectedness of the pore spaces and their size. Fluid can flow more easily through a material with large pores and good connectivity and also when fractures are present (Lee and Farmer, 1990; Wang et al., 2009). Permeability depends strongly on grain size, as coarse-grained rocks (e.g., sandstones) have larger pores and higher permeability (Hyne, 2001). Permeability is an important consideration for the subsurface, as it controls the flow of water, carbon dioxide, and nutrients (Gold, 1992; Pedersen, 1993). Depth is the strongest control on subsurface permeability; however, permeability strongly decreases at 
the brittle-ductile transition (Ingebritsen and Manning, 1999; $\sim 10-15 \mathrm{~km}$ depth on Earth) due to the decreased fracturing and porosity of the rocks at this depth. Although the permeability-depth variation on Mars is not known, it is likely that the martian subsurface (whether basaltic, plutonic, or ice-rich) is permeable down to $1 \mathrm{~km}$ depth. Below that, permeability may extend to a depth of $\sim 85 \mathrm{~km}$, considering only compaction effects. The depth of the brittle-ductile transition, however, will strongly affect the permeability profile, and its depth will vary with rock composition and ice content and is not well known.

\subsection{Potential biosphere phase model}

Jones and Lineweaver (2010) quantified terrestrial liquid water environments that do not currently support life. One such environment was cold liquid water at temperatures below $-20^{\circ} \mathrm{C}$ (the minimum temperature for active lifeJunge et al., 2004) where liquid water exists as a brine or thin film. If the low activity limit of 0.6 for life is real, then terrestrial-like life on Mars may be restricted to liquid water environments above $\sim-20^{\circ} \mathrm{C}$. This estimate can be improved when the subzero activities of the salts mentioned above are better constrained. Temporary access to water at a tolerable low activity level may, however, be sufficient for life to thrive on Mars.

Although liquid water is known to be present at extremely low temperatures in soil, the thickness of the thin films present may also be a limiting factor for biology. The mass of unfrozen water in terrestrial permafrost below $-20^{\circ} \mathrm{C}$ is $1 \%$ by weight (Rivkina et al., 2000). In these soils, bacterial cells are covered by thin films of water that allow for nutrients and waste exchange through diffusion in the films. This process, however, is limited by the thickness of the films, which depends on temperature (Rivkina et al., 2000; Jakosky et al., 2003). Rivkina et al. (2000) hypothesized that, as temperature and the thickness of the films decrease the diffusion, gradients will slow, and eventually the movement of nutrients and waste materials will cease. However, the temperature at which this will prevent active growth and metabolism is not known.

Even when water activity is not a limit, only extremely coldtolerant organisms will be able to metabolize and grow at temperatures $<-20^{\circ} \mathrm{C}$, and chemical reactions will be slow. Experiments by Mazur (1980) on yeast identified that most cells remain unfrozen at $-15^{\circ} \mathrm{C}$, as the cell membrane is able to block the passage of ice crystals and of supercooled water in the cell. Intracellular fluid moves through the cell membrane from high- to low-activity water. This causes the remaining fluid in the cell to have a higher ion concentration, which further lowers its activity (Gunde-Cimerman et al., 2003). This process, caused by a water activity gradient, can cause irrevocable damage to the cell if the fluid freezes. The lowest activity in which a cell can survive the freezing process, however, is not known. Extracellular liquid water is, however, necessary for cell function and growth (Mazur, 1980), although there is increasing interest in determining whether water vapor can suffice given the daily variation and temporary saturation of water vapor on Mars (e.g., Möhlmann, 2005). Some terrestrial lichens may be able to survive on water vapor under martian conditions (de Vera et al., 2010) in a manner similar to that demonstrated by Atacama Desert cyanobacteria at high humidity (Wierzchos et al., 2011). Minerals with hygroscopic properties (able to attract moisture from the atmosphere) such as perchlorates (found by the Phoenix lander on Mars and in the Atacama Desert; Schulze-Makuch and Houtkooper, 2010) and hydrogen peroxide (Houtkooper and Schulze-Makuch, 2007) could be utilized by organisms to harvest water vapor through the process of deliquescence (observed in cyanobacteria; Davila et al., 2008).

Ultimately, life may be fundamentally limited by water activity (Gunde-Cimerman et al., 2003) - due to high concentrations of solutes and subzero temperatures. Psychrophiles may be able to remain active at temperatures down to $-50^{\circ} \mathrm{C}$ if they utilize metastable supercooled liquid water; however, they will face the additional challenges of lowactivity intracellular fluid and slow diffusion gradients.

Terrestrial psychrophiles and halobacteria that grow in low temperature, high salinity, and desiccated environments (e.g., permafrost and ice) may be well suited to the shallow martian subsurface ( $\sim 10$ s of centimeters) if liquid water is present (Horneck, 2000, 2008; Landis, 2001; Mancinelli et al., 2004; Pavlov et al., 2010). Deep subsurface anaerobic life (e.g., methanogens) beneath the martian cryosphere ( kilometers depth) is also possible if liquid water and an energy source (e.g., the radiolysis of water; Chivian et al., 2008) are available (Boston et al., 1992; Szewzyk and Szewzyk, 1994). At temperatures above $-20^{\circ} \mathrm{C}$, films of liquid water adsorbed on grains in the soil may be several micrometers thick and have an activity above the currently assumed minimum of 0.6 for life (Jakosky et al., 2003; Möhlmann, 2004, 2008). Such an environment may be habitable to lithoautotrophic life, which can utilize thin films (Jepsen et al., 2007). Also subsurface brines may provide suitable habitats for organisms such as the active Cytophaga-Flavobacteria found $2.75 \mathrm{~km}$ deep within an Arctic ice core at $-20^{\circ} \mathrm{C}$ (Junge et al., 2004).

The potential martian biosphere also identifies planetary protection regions (Chyba et al., 2006). If environments within the potential martian biosphere were contaminated by life on Earth, the conditions are hospitable to the survival and potential growth of terrestrial organisms, where liquid water with an activity above 0.6 is present. Environments identified as lying within the potential martian biosphere should be added to the list of currently designated special regions (including gullies, pasted terrain, etc.; Beaty et al., 2006) to prevent forward contamination. The identification of near-subsurface environments on Mars that have the potential for liquid water is relevant to NASA's Mars Science Laboratory (MSL) mission launched in November 26, 2011 (McCleese et al., 2003). Through a neutron spectrometer, MSL will have the capability to measure the concentration of adsorbed water $\left(\mathrm{H}_{2} \mathrm{O}\right)$ and hydrated minerals $(\mathrm{OH})$ to $\sim 0.3$ $\%$ wt accuracy in the top $\sim 1 \mathrm{~m}$ of martian soil (Litvak et al., 2008). The landing site at Gale Crater is located at low elevation and absolute latitude $<27^{\circ}$ (Golombek et al., 2011). Our results on the depth of the potential martian biosphere in absolute latitudes $\leq 30^{\circ}$ support the astrobiological significance of the MSL landing site.

\section{Conclusions}

Given our current understanding of terrestrial life, the maximum possible depth of the martian biosphere is the $122^{\circ} \mathrm{C}$ isotherm. We have shown that there are subsurface environments on Mars to a depth of $\sim 36 \pm{ }_{30}^{14} \mathrm{~km}$, where the pressure 
and temperature conditions from modeled geotherms both overlap the phase space of active terrestrial life and allow water, if it is present, to exist as a liquid. If evidence for water is found in these environments, then they have a high potential of supporting terrestrial-like life. The availability of nutrients and free energy (rather than temperature) may also have an important role in setting the depth limit of life on Mars. Permeability may not be a limiting factor for life on Mars; taking compaction effects into consideration, the crust may be permeable to $\sim 85 \mathrm{~km}$, which is most likely beneath the maximum depth of the biosphere. Hence, many subsurface environments on Mars should be hospitable for psychrophilic, halophilic oligotrophic terrestrial life.

\section{Appendix A}

The subsurface pressure and temperature gradient of any planet are proportional to each other and are related through density, conductivity, and heat production. This relationship determines the P-T space occupied by Mars.

\section{A.1. Core}

Mars' core extends from a depth of $1630-3390 \mathrm{~km}$. The core size, composition, and temperature profile are estimated from Mars' polar moment of inertia (Folkner et al., 1997) measured from orbit. The moment of inertia indicates the distribution of mass within the planet (Barlow, 2008) and so can constrain the plausible combinations of core sizes and masses/densities. At the center, the core pressure in our model is $4.11 \times 10^{10} \mathrm{~Pa}$ (Sohl and Spohn, 1997). Estimates for this pressure range predominantly between $3.8 \times 10^{10}$ and $5 \times 10^{10} \mathrm{~Pa}$ (with a low-pressure estimate of $2.4 \times 10^{10} \mathrm{~Pa}$ by Fei and Bertka, 2005), which makes our choice a reasonable representation. Variation in estimates for the central core pressure is due to the poor constraints on the composition of the inner core, which results in significantly different geotherms (Gudkova and Zharkov, 2004). Core composition is estimated predominantly from the isotopic composition of SNC meteorites (Lodders and Fegley, 1998). Central core temperatures are modeled to lie between 1950 and $3000 \mathrm{~K}$; however, recent modeling favors the cooler end of this range around $2000 \mathrm{~K}$ (Fei and Bertka, 2005; Connolly and Khan, 2006). Hence, we have used this value in our model. The estimates for Mars' core temperature are significantly less than that for Earth $(5700 \mathrm{~K})$, which highlights the advanced stage of cooling of Mars' core and the lower heat flow across the planet's surface. The central core and core-mantle boundary in Fig 1. have horizontal error bars describing the uncertainty in their temperatures.

For the core-mantle boundary (CMB), we have used a representative pressure of $2.3 \times 10^{10} \mathrm{~Pa}$ (Sohl and Spohn, 1997). The model-dependent temperature estimates for the CMB range between 1650 and $1900 \mathrm{~K}$, and we have adopted a representative $\mathrm{CMB}$ temperature of $1700 \mathrm{~K}$, as this is favored by more recent "cool" models (Fei and Bertka, 2005; Verhoeven et al., 2005; Connolly and Khan, 2006). On Earth, the mantle-to-core density transition occurs within a thin layer characterized by a steeper geothermal gradient than either mantle or core. The same may be true of Mars. The phase of the present-day martian core is dependent on its exact mineralogy; however, a liquid core is consistent with both Mars' moment of inertia (Barlow, 2008) and with data on mineral transition experiments for the estimated core composition (Bertka and Fei, 1997). However, Mars exhibits only a very weak magnetic field, which indicates that it does not have an active dynamo; hence, its inner core must have either completely solidified or, if liquid, be in very slow motion (Longhi et al., 1992).

Between our chosen boundary values, the average geotherm within Mars' core is $0.74 \mathrm{~K} / \mathrm{km}$. This is comparable to the models for Earth's core geotherm $(0.8 \mathrm{~K} / \mathrm{km})$. The temperatures and pressures along our average geotherm imply a liquid core for a model composition of iron and sulfur, with $14.2 \%$ wt S (Fei and Bertka, 2005; the sulfur content can be varied while still remaining above the melting line). A Fe-Ni$\mathrm{S}$ core would also be molten as the modeled geotherm is above the minimum eutectic.

\section{A.2. Mantle}

Mars' mantle extends from an average of $\sim 1630 \mathrm{~km}$ below the surface to the base of the martian crust. The upper boundary beneath the crust is poorly constrained by gravity and topography data, which indicate that the range of crustal thickness is $\sim 35-100 \mathrm{~km}$ (see discussion in Crust). We have used a representative depth of the martian Moho of $50 \mathrm{~km}$ under the surface (a reasonable average from Neumann et al., 2004; Wieczorek and Zuber, 2004). Using $2900 \mathrm{~kg} / \mathrm{m}^{3}$ for the crustal density (Zuber, 2001), low gravity of $3.7 \mathrm{~m} / \mathrm{s}^{2}$, and an average crustal geotherm of $\sim 4.5 \mathrm{~K} / \mathrm{km}$ (McKenzie et al., 2002; Verhoeven et al., 2005) gives a pressure and temperature of $5.4 \times 10^{8} \mathrm{~Pa}$ and $450 \mathrm{~K}$, respectively, at the depth of the Moho. Some older estimates (including "hot models") predict the crust-mantle boundary temperature between 1300 and $1700 \mathrm{~K}$ (Sohl and Spohn, 1997; Lodders and Fegley, 1998). These models, however, assume a thick $200 \mathrm{~km}$ crust, which is inconsistent with more recent high-resolution topography and gravity field data from Mars Global Surveyor. Given our CMB values, our chosen average Moho leads to a mantle geotherm of $0.85 \mathrm{~K} / \mathrm{km}$ (Earth model mantle gradient $0.7 \mathrm{~K} / \mathrm{km}$-Jones and Lineweaver, 2010).

\section{A.3. Crust}

There has never been a direct estimate of the crustal heat flow of Mars; however, scaling of terrestrial values can be carried out under the assumption that smaller planetary masses have lower core and mantle temperatures and lower surface heat flow (Papuc and Davies, 2008). The net heat flow on Mars combines contributions from the secular cooling of the core and from the decay of radiogenic elements in the planet's crust and mantle (Hahn and McLennan, 2008). The present-day heat flow from radioactivity is estimated to be around $5 \mathrm{~mW} /$ $\mathrm{m}^{2}$ (Hahn and McLennan, 2008), with the estimates for the total heat flow ranging from 15 to $55 \mathrm{~mW} / \mathrm{m}^{2}$ (Toksöz and Hsui, 1978; Solomon and Head, 1990; Hoffman, 2000; Andersen et al., 2002; Urquhart and Gulick, 2002).

Additional variation in the martian geotherm arises (as it does on Earth) due to the variation in thermal conductivity of different crustal materials on Mars (e.g., water and $\mathrm{CO}_{2}$ ice have a significantly lower conductivity than rock: James, 1968; Clifford, 1987; Mellon, 1996). Taking a range of 0.001$4.5 \mathrm{~W} / \mathrm{m} / \mathrm{K}$ for martian materials, combined with the variation in heat flow estimates, provides a range of geothermal gradients from $4 \times 10^{4}$ to $5.5 \times 10^{4} \mathrm{~K} / \mathrm{km}$. The extremely high 
Table A1. Model Parameters for Mars' Core, Mantle, Crust, and Atmosphere

\begin{tabular}{|c|c|c|}
\hline Region & Range & Reference \\
\hline \multicolumn{3}{|l|}{ Core } \\
\hline Temperature (K) & $2200 \pm{ }_{250}^{800}$ (inner) to $1800 \pm{ }_{180}^{200}$ (outer) & $\begin{array}{l}\text { Lodders and Fegley, 1998; Fei and Bertka, } \\
\text { 2005; Sohl and Spohn, 1997; Connolly } \\
\text { and Khan, 2006; Verhoeven et al., } 2005\end{array}$ \\
\hline Pressure $(\mathrm{Pa})$ & $\begin{array}{l}\left(4.1 \pm_{1.6}^{0.9}\right) \times 10^{10} \text { (inner) to }\left(2.3 \pm \pm_{1.0}^{0.9}\right) \times 10^{10} \\
\quad \text { (outer) }\end{array}$ & $\begin{array}{l}\text { Lodders and Fegley, 1998; Fei and Bertka, } \\
\text { 2005; Sohl and Spohn, 1997; Verhoeven } \\
\text { et al., } 2005\end{array}$ \\
\hline Depth $(\mathrm{km})$ & 1630 (outer) to 3390 (inner) & Lodders and Fegley, 1998 \\
\hline Density $\left(\mathrm{kg} / \mathrm{m}^{3}\right)$ & 7300 & Lodders and Fegley, 1998 \\
\hline Geothermal gradient $(\mathrm{K} / \mathrm{km})$ & 0.740 & $\begin{array}{l}\text { Fei and Bertka, 2005; Sohl and Spohn, } \\
\text { 1997; Verhoeven et al., } 2005\end{array}$ \\
\hline \multicolumn{3}{|r|}{ - } \\
\hline Temperature (K) & $1800 \pm{ }_{180}^{200}$ (inner) to $450 \pm{ }_{150}^{350}$ (outer) & $\begin{array}{l}\text { Lodders and Fegley, 1998; Sohl and } \\
\text { Spohn, 1997; Verhoeven et al., 2005; } \\
\text { Longhi et al., 1992; Bertka and Fei, 1997; } \\
\text { McKenzie et al., } 2002\end{array}$ \\
\hline Pressure $(\mathrm{Pa})$ & 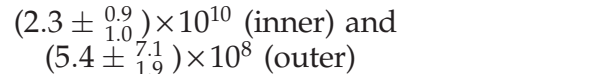 & $\begin{array}{l}\text { Lodders and Fegley, 1998; Sohl and } \\
\text { Spohn, 1997; Verhoeven et al., } 2005\end{array}$ \\
\hline Depth $(\mathrm{km})$ & 50 (inner) and 1630 (outer) & McGovern et al., 2002, 2004 \\
\hline Density $\left(\mathrm{kg} / \mathrm{m}^{3}\right)$ & 3500 & McGovern et al., 2002 \\
\hline Geothermal gradient $(\mathrm{K} / \mathrm{km})$ & 0.85 & $\begin{array}{l}\text { Sohl and Spohn, 1997; Verhoeven et al., } \\
2005\end{array}$ \\
\hline \multicolumn{3}{|l|}{ Crust } \\
\hline Temperature (K) & $\begin{array}{l}140-300 \text { (surface) } \sim 450 \pm{ }_{100}^{470} \text { (at base, } \\
50 \mathrm{~km} \text { ) }\end{array}$ & $\begin{array}{l}\text { Lodders and Fegley, 1998; Sohl and } \\
\text { Spohn, 1997; Verhoeven et al., } 2005\end{array}$ \\
\hline Pressure (Pa) & $\begin{array}{l}250-1200(\text { surface }) \sim(5.4 \pm 7.1 \\
\quad(\text { at base, } 50 \mathrm{~km})\end{array}$ & $\begin{array}{l}\text { McGovern et al., 2002; Wieczorek and } \\
\text { Zuber, } 2004\end{array}$ \\
\hline Depth $(\mathrm{km})$ & $\begin{array}{l}35-100 \text { majority in } 32-62 \text { average } \sim 32 \text { in } \\
\text { north; } \sim 58 \text { in south; globally } 50\end{array}$ & $\begin{array}{l}\text { Turcotte et al., 2002; Zuber et al., 2000; } \\
\text { Wieczorek and Zuber, 2004; Neumann } \\
\text { et al., } 2004\end{array}$ \\
\hline Density $\left(\mathrm{kg} / \mathrm{m}^{3}\right)$ & $2900-3100$ & Turcotte et al., 2002; McGovern et al., 2002 \\
\hline $\begin{array}{l}\text { Geothermal gradient } \\
(\mathrm{K} / \mathrm{km})\end{array}$ & $\begin{array}{l}\text { 4.5; range } 4-15 \text { few estimates in range } \\
20-25\end{array}$ & $\begin{array}{l}\text { Urquhart and Gulick, 2002; Solomon and } \\
\text { Head, 1990; Hoffman, 2000; McGovern } \\
\text { et al., 2002; Andersen et al., } 2002\end{array}$ \\
\hline \multicolumn{3}{|l|}{ Atmosphere } \\
\hline $\begin{array}{l}\text { Mean lapse rate } \\
\text { temperature }(\mathrm{K} / \mathrm{km})\end{array}$ & 1.1 & Barth, 1974; Conrath et al., 2000 \\
\hline $\begin{array}{l}\text { Lapse rate pressure } \\
(\mathrm{Pa} / \mathrm{km})\end{array}$ & 8.6 & Barth, 1974; Conrath et al., 2000 \\
\hline
\end{tabular}

geotherms correspond to layers of low-conductivity materials (sand and dust), which would only constitute a very thin layer on the martian surface (dust typically $<5 \mathrm{~m}$ thickChristensen, 1986; sand in martian dunes can form deposits tens of meters high-Bourke et al., 2006). For reference, terrestrial geotherms in rock (in the oceanic and continental crust) vary predominantly between 5 and $70 \mathrm{~K} / \mathrm{km}$. The variation in the crustal geotherm in rocks and ice leads to a range of Moho temperatures for a given crustal depth, as indicated by points E, F, and G in Fig. 1.

Present estimates of Mars' crustal thickness are based on indirect geophysical studies involving local relationships between gravity, topography, and geochemistry (Sohl et al., 2005). Estimates of crustal thickness range from 30 to $100 \mathrm{~km}$ (Zuber, 2001; Turcotte et al., 2002) with a global average of $50 \mathrm{~km}$ (Neumann et al., 2004; Wieczorek and Zuber, 2004). This is a considerably smaller range than earlier estimates (predating Mars Global Surveyor's revised topography and gravity results), which placed the thickest regions of the crust at $200 \mathrm{~km}$ with a typical value of $100 \mathrm{~km}$ (Sohl and Spohn, 1997; Zuber et al., 2000). Estimates of pressure within the crust (from mass overburden) assume an average crustal density within the range of $2700 \mathrm{~kg} / \mathrm{m}^{3}$ (representative of andesitic-basaltic composition from Pathfinder measurements of soil-free rocks) to $3100 \mathrm{~kg} / \mathrm{m}^{3}$ (from porous basaltic shergottites interpreted as martian crust samples; Britt and Consolmagno, 2003). Our pressure values for the base of the crust are based on a density of $2900 \mathrm{~kg} / \mathrm{m}^{3}$ (McGovern et al., 2002; Turcotte et al., 2002) for crust $<50 \mathrm{~km}$ thick and 3100 $\mathrm{kg} / \mathrm{m}^{3}$ for up to $100 \mathrm{~km}$ thick crust (McGovern et al., 2002), leading to a range of $(0.38-1.2) \times 10^{9} \mathrm{~Pa}$ at the base of the crust. The Moho has both a vertical error bar describing the uncertainty in depth and a slanted error bar describing the uncertainty in temperature. The temperature error bar is slanted as a shallow Moho will generally have a lower temperature than a deep Moho.

The error bars at the Moho in Fig. 1 indicate that our modeled maximum crustal thickness (maximum Moho depth) is $100 \mathrm{~km}$ (points F and G; Sohl et al., 2005), with the maximum crustal temperature between $377^{\circ} \mathrm{C}$ (point F) and $650^{\circ} \mathrm{C}$ (point $\mathrm{G})$. This range is consistent with a crustal geothermal gradient of $4-7 \mathrm{~K} / \mathrm{km}$ as estimated for present-day Mars (McGovern 
et al., 2002, 2004) and giving the estimated maximum temperature of the martian Moho as $650^{\circ} \mathrm{C}$ (Zuber et al., 2000).

The martian heat flow dominates the subsurface geothermal gradient below $\sim 20 \mathrm{~m}$ depth (Pollack and Huang, 2000). Above this depth the temperature profile is dominated by solar heating, shown in Fig. 4. Heat flux can be converted to a geothermal gradient by using thermal conductivity (Stüwe, 2007; p 93) through

$$
Q=-k(d T / d r)
$$

where $Q$ is heat flow $\left(\mathrm{W} / \mathrm{m}^{2}\right), k$ is thermal conductivity (W/ $\mathrm{m} / \mathrm{K})$ and $d T / d r$ is the geotherm $(\mathrm{K} / \mathrm{km})$. Considering only the downward conduction of solar heat, the temperature at depth $y$ beneath the surface is

$$
T(y)=T_{o}+y(d T / d r)
$$

where $T_{\mathrm{o}}$ is the surface temperature. We take the average surface temperature on Mars to be $T_{\mathrm{o}}=-63^{\circ} \mathrm{C}$. As we are interested in the average depths to the extreme thermal limits on terrestrial life, we can use Eqs. 1 and 2 to model the depth at which $T_{\max }=122^{\circ} \mathrm{C}$ and $T_{\min }=-20^{\circ} \mathrm{C}$ are obtained:

$$
y_{\min }^{\max }=\left(T_{\min }^{\max }-T_{o}\right) /(d T / d r)=\left(T_{\min }^{\max }-T_{o}\right)(-k / Q)
$$

which yields

$$
\begin{gathered}
y_{\max }=185 /(d T / d r)=185(-k / Q) \\
y_{\text {min }}=43 /(d T / d r)=43(-k / Q)
\end{gathered}
$$

With the average crustal geotherm on Mars $d T / d r \sim 5 \mathrm{~K} / \mathrm{km}$ (see Table A1), we obtain $y_{\max }=37 \mathrm{~km}$ and $y_{\min }=9 \mathrm{~km}$. These values represent an estimate of the average depths to the isothermal boundaries of subsurface life on Mars.

\section{Appendix B}

(See Table B1.)

\begin{tabular}{|c|c|c|c|c|}
\hline Key & Description & $\begin{array}{l}\text { Pressure (bar) } \\
\text { Depth }(\mathrm{km})\end{array}$ & $\begin{array}{l}\text { Temp } \\
\left({ }^{\circ} \mathrm{C}\right)\end{array}$ & Reference \\
\hline 1 & Mt. Everest summit & $\begin{array}{l}0.33 \pm 0.01 \\
-8.848\end{array}$ & -20 & $\begin{array}{l}\text { Active microbial life has not been searched for at } \\
\text { this location. We set } 1 \text { at the same minimum } \\
\text { temperature at which active life has been found } \\
\text { (see } 8 \text { ). Gangwar et al. (2009) report life at }-20^{\circ} \mathrm{C} \\
\text { at } 5.6 \mathrm{~km} \text {. }\end{array}$ \\
\hline 2 & $\begin{array}{l}\text { Thermal spring/vent (Pork } \\
\text { Chop Geyser, Yellowstone } \\
\text { National Park, USA) }\end{array}$ & $\begin{array}{c}0.77 \\
-2.293\end{array}$ & 97 & Guidry and Chafetz (2003) (Lilypad stromatolites) \\
\hline 3 & Shallow hydrothermal vents & $\begin{array}{c}2 \\
0.01\end{array}$ & 122 & $\begin{array}{l}\text { Thermophilic life has been found in shallow vents } \\
\text { at temperatures between } 40^{\circ} \mathrm{C} \text { and } 100^{\circ} \mathrm{C} \\
\text { (Amend et al., 2003; Prol-Ledesma, } 2003 \text {; Stetter, } \\
\text { 2006). Life has not been found at the maximum } \\
\text { temperature of } 122^{\circ} \mathrm{C} \text { (see } 4 \text { ); however, } \\
\text { temperatures of vents at this depth can exceed } \\
122^{\circ} \mathrm{C} \text { (Prol-Ledesma, 2003). We have therefore } \\
\text { placed this marker at a temperature of } 122^{\circ} \mathrm{C} \text {. }\end{array}$ \\
\hline 4 & $\begin{array}{l}\text { Ocean hydrothermal vent } \\
\text { where highest-temperature } \\
\text { life found (Finn Vent, } \\
\text { Mothra Field, Pacific Ocean) }\end{array}$ & $\begin{array}{l}2.1 \times 10^{2} \\
2.27\end{array}$ & 122 & $\begin{array}{l}\text { Takai et al. (2008) and Kashefi and Lovley (2003) } \\
\text { (Archaea, closely related to closely related to } \\
\text { Pyrodictium occultum, Pyrobaculum aerophilum) } \\
\text { Schrenk et al. (2003) }\end{array}$ \\
\hline 5 & $\begin{array}{l}\text { Marianas trench, deepest part } \\
\text { of ocean (Challenger Deep, } \\
\text { Pacific Ocean) }\end{array}$ & $\begin{array}{l}1.32 \times 10^{3} \\
10.924\end{array}$ & 122 & $\begin{array}{l}\text { Thermophilic life has not been searched for at this } \\
\text { location. Life could exist in this environment, as } \\
\text { the maximum temperature for life found thus far } \\
\text { is } 122^{\circ} \mathrm{C} \text { (see marker 4), and vents at this depth } \\
\text { can exceed } 122^{\circ} \mathrm{C} \text { (Mariana Trench, } 2003 \\
\text { website), and life has been found at } 2-3^{\circ} \mathrm{C} \\
\text { temperatures in this environment (Todo et al., } \\
\text { 2005). We have therefore placed this marker at a } \\
\text { temperature of } 122^{\circ} \mathrm{C} \text {. }\end{array}$ \\
\hline 6 & $\begin{array}{l}\text { Deepest active life in crust } \\
\text { from borehole (Gravberg, } \\
\text { Sweden) }\end{array}$ & $\begin{array}{l}1.55 \times 10^{3} \\
5.278\end{array}$ & 75 & $\begin{array}{l}\text { Szewzyk and Szewzyk (1994) (Thermoanaerobacter, } \\
\text { Thermoanaerobium, Clostridium, close relationship } \\
\text { to Clostridium thermohydrosulfuricum) }\end{array}$ \\
\hline 7 & $\begin{array}{l}\text { Marianas trench (Challenger } \\
\text { Deep, Pacific Ocean) }\end{array}$ & $\begin{array}{l}1.32 \times 10^{3} \\
10.896\end{array}$ & 2 & $\begin{array}{l}\text { Todo et al. (2005), Takami et al. (1997) (Foraminifera: } \\
\text { Lagenammina, Nodellum, Resigella) }\end{array}$ \\
\hline 8 & $\begin{array}{l}\text { Arctic ice core, lowest- } \\
\text { temperature active life }\end{array}$ & $\begin{array}{l}10^{2} \\
2.75\end{array}$ & -20 & $\begin{array}{l}\text { Junge et al. (2004) [Bacteria (EUB338), Cytophaga- } \\
\text { Flavobacteria (CF319a), Archaea (ARCH915)] }\end{array}$ \\
\hline
\end{tabular}

\section{Appendix C}

Figure 4 presents the annual variation in shallow subsurface geotherms established by solar heating on present-day

Table B1. Active Life Environments 
Table B2. Dormant Life Environments

\begin{tabular}{|c|c|c|c|c|c|}
\hline Key & Description & $\begin{array}{l}\text { Pressure (bar) } \\
\text { Depth }(\mathrm{km})\end{array}$ & $\begin{array}{l}\text { Temp } \\
\left({ }^{\circ} \mathrm{C}\right)\end{array}$ & Reference & Metabolic activity \\
\hline 9 & Vostok ice core life & $\begin{array}{c}10^{2} \\
2.75\end{array}$ & -40 & $\begin{array}{l}\text { Abyzov et al., 1998; } \\
\text { Price and Sowers, } 2004\end{array}$ & $\begin{array}{l}\text { Cell activity after incubation; } \\
\text { interpreted as cells in situ were } \\
\text { able to maintain vital functions } \\
\text { but not reproduce }\end{array}$ \\
\hline 10 & $\begin{array}{l}\text { Greenland open } \\
\text { mine life }\end{array}$ & 1 & -30 & $\begin{array}{l}\text { Langdahl and } \\
\text { Ingvorsen, } 1997\end{array}$ & $\begin{array}{l}\text { Sampled at warmer temperatures so } \\
\text { metabolic activity at low } \\
\text { temperature limit is unknown } \\
\text { (Thiobacillus ferrooxidans, } \\
\text { Thiobacillus thiooxidans, and } \\
\text { Leptospirillum ferrooxidans) }\end{array}$ \\
\hline 11 & $\begin{array}{l}\text { Mt. Everest } \\
\text { summit }\end{array}$ & $\begin{array}{l}0.33 \pm 0.01 \\
-8.848\end{array}$ & -40 & & $\begin{array}{l}\text { Marker } \mathbf{1 1} \text { is at the minimum } \\
\text { temperature at which dormant } \\
\text { microbial life has been found in } \\
\text { the crust in the presence of liquid } \\
\text { water (see 9), and the pressure is } \\
\text { given by } \mathbf{1 .}\end{array}$ \\
\hline 12 & $\begin{array}{l}\text { Bacterial spores } \\
\text { (atmosphere) }\end{array}$ & $\begin{array}{c}0.0553^{*} \\
-20\end{array}$ & $-20^{*}$ & $\begin{array}{l}\text { Wainwright } \\
\text { et al., } 2002\end{array}$ & $\begin{array}{l}\text { Dormant (spore) in atmosphere but } \\
\text { cultured in laboratory (Bacillus } \\
\text { simplex, Staphylococcus asteuri, } \\
\text { Engyodontium album) }\end{array}$ \\
\hline 13 & $\begin{array}{l}\text { Non-spore-forming } \\
\text { eubacteria } \\
\text { (atmosphere) }\end{array}$ & $\begin{array}{c}0.0025^{*} \\
-41\end{array}$ & $-56^{*}$ & Griffin, 2008 & $\begin{array}{l}\text { Growth after extended incubation } \\
\text { (Micrococcaceae, } \\
\text { Microbacteriaceae, Brevibacterium } \\
\text { luteolum, Staphylococcus) }\end{array}$ \\
\hline 14 & $\begin{array}{l}\text { Bacterial spores } \\
\text { (atmosphere) }\end{array}$ & $\begin{array}{c}0.00002^{*} \\
-77\end{array}$ & $-69^{*}$ & $\begin{array}{r}\text { Imshenetsky } \\
\text { et al., } 1978\end{array}$ & $\begin{array}{l}\text { Dormant (spore) in atmosphere } \\
\text { (Circinella muscae, Aspergillus } \\
\text { niger, Papulaspora anomala, } \\
\text { Penicillium notatum, } \\
\text { Mycobacterium luteum, Micrococcus } \\
\text { albus) }\end{array}$ \\
\hline
\end{tabular}

*Temperature and pressure from Hewitt and Jackson (2003).

Mars, calculated from a one-dimensional heat-conduction model (Turcotte and Schubert, 1982, p 134). It is assumed that there is no heat source in the soil, which is most likely valid in the small depth range over which the model is applied. The downward conduction of thermal waves is dependent on the thermal diffusivity $\left(\mathrm{m}^{2} / \mathrm{s}\right)$ of the medium, given by $\kappa=\frac{k}{\rho C}$ where $k=$ thermal conductivity $(\mathrm{W} / \mathrm{m} / \mathrm{K})$, $\mathrm{C}=$ specific heat capacity $(\mathrm{J} / \mathrm{kg} / \mathrm{K})$ and $\rho=\operatorname{density}\left(\mathrm{kg} / \mathrm{m}^{3}\right)$. It is also dependent on the timescales of interest. The attenuation of thermal waves is frequency-dependent, with longer-period waves attenuating less with depth than shorterperiod waves (Pollack and Huang, 2000). If temperature

Table C1. Model Parameters for Mars' Subsurface Temperatures

\begin{tabular}{|c|c|c|c|c|c|c|c|c|}
\hline Material & $\begin{array}{l}\text { Thermal } \\
\text { conductivity } \\
\left(W m^{-1} K^{-1}\right)\end{array}$ & $\begin{array}{l}\text { Density } \\
\left(\mathrm{kg} \mathrm{m}^{-3}\right)\end{array}$ & $\begin{array}{c}\text { Heat } \\
\text { capacity } \\
\left(J \mathrm{~kg}^{-1} \mathrm{~K}^{-1}\right)\end{array}$ & $\begin{array}{l}\text { Thermal } \\
\text { diffusivity } \\
\left(m^{2} s^{-1}\right)\end{array}$ & $\begin{array}{l}\text { Skin } \\
\text { depth } \\
(m)\end{array}$ & $\begin{array}{l}\text { Calculated } \\
\text { thermal } \\
\text { inertia }\end{array}$ & $\begin{array}{l}\text { Calculated } \\
\text { geotherm } \\
\left(\mathrm{K} \mathrm{km}^{-1}\right) \\
\text { (heat flow } 15 \\
\left.m W \mathrm{~m}^{-2}\right)\end{array}$ & References \\
\hline Dust & 0.001 & 1000 & 800 & $1.3 \times 10^{-9}$ & 0.2 & 28 & $1.5 \times 10^{4}$ & Mellon, 2001 \\
\hline $\begin{array}{l}\text { Coarser } \\
\text { fines }\end{array}$ & 0.1 & 1750 & 800 & $7.1 \times 10^{-8}$ & 0.6 & 374 & 150 & $\begin{array}{l}\text { Mellon, 2001; Heldmann et al., } \\
\text { 2005; Murphy et al., } 2009\end{array}$ \\
\hline Duricrust & 0.3 (up to 2) & 1750 & 800 & $2 \times 10^{-7}$ & 2 & 648 & 50 & $\begin{array}{l}\text { Murphy et al., 2009; Piqueux } \\
\text { and Christensen, } 2009\end{array}$ \\
\hline Icy soil & 2.5 & 2018 & 1040 & $1.2 \times 10^{-6}$ & 0.8 & 2294 & 6 & $\begin{array}{l}\text { Mellon et al., 2004; Sizemore } \\
\text { and Mellon, } 2006\end{array}$ \\
\hline Rock & $\begin{array}{l}2.5 \text { (range } \\
\text { generally } \\
1.5-4.5 \text { ) }\end{array}$ & 2900 & 800 & $1 \times 10^{-6}$ & 3.1 & 2408 & 6 & $\begin{array}{l}\text { Clauser and Huenges, 1995; } \\
\text { Turcotte et al., 2002; } \\
\text { Sizemore and Mellon, } \\
\text { 2006; Mellon, } 2001\end{array}$ \\
\hline $\mathrm{H}_{2} \mathrm{O}$ ice & $\begin{array}{l}3.4\left(\text { at }-110^{\circ} \mathrm{C} ;\right. \\
\left.\quad 2 \text { at } 0^{\circ} \mathrm{C}\right)\end{array}$ & 928 & 1310 & $1.3 \times 10^{-6}$ & 5.0 & 2044 & 4 & $\begin{array}{l}\text { Clauser and Huenges, } \\
\text { 1995; Titus et al., } 2003\end{array}$ \\
\hline
\end{tabular}


changes occur within a time interval gamma, $\Gamma$ (e.g., $8640 \mathrm{~s}$ for diurnal variations), they will propagate $\sim \sqrt{\kappa \Gamma}$ meters into the subsurface. As thermal waves propagate through the subsurface, their amplitude diminishes exponentially with depth from the surface. Diurnal and seasonal variations typically cannot be detected at depths greater than meters or tens of meters, respectively; whereas long-term temperature trends (such as obliquity changes) can penetrate to approximately kilometers (Pollack and Huang, 2000).

We follow the notation of Turcotte and Schubert (1982, chapter 4 ). Surface heat variations are modeled as sinusoidal curves, given by

$$
T_{s}(t)=T_{0}+\Delta T \cos \omega t
$$

where $T_{\mathrm{s}}$ is the temperature on the surface; $T_{\mathrm{o}}$ is the average surface temperature, $\Delta T$ is the amplitude of variation around $T_{\mathrm{o}}$ (e.g., $\Delta T=40 \mathrm{~K}$ in Fig. 4 ) and $\omega=2 \pi f$ where $f$ is the frequency (i.e., daily or yearly). Depth- and time-dependent subsurface temperatures are then given by

$$
T_{\text {sub }}(y, t)=T_{o}+\Delta T \exp \left(-y / d_{\omega}\right) \cos \left(\omega t-y / d_{\omega}\right)
$$

where $y=$ depth beneath the surface; the skin depth $d_{\omega=}(2 \kappa /$ $\omega)^{1 / 2}$ where the thermal diffusivity $\kappa=k / \rho C$, where $\rho$ is density and $C$ is specific heat capacity. Since the maximum and minimum of the cos term are +1 and -1 , the envelope of the maximum and minimum temperatures around the average temperature, $T_{\mathrm{o}}+y d T / d r$, at depth $y$ are given by

$$
T^{\max } \min (y)=\left(T_{o}+y d T / d r\right)+\Delta T \exp \left(-y / d_{\omega}\right)
$$

and are plotted in Fig. 4.

The thermal diffusivities and skin depths used for each material in Fig. 4 are given in Table C1. This model is oversimplified, as the range of temperatures experienced by a material on the surface is dependent on its albedo. Hence, the surface temperature range experienced by dust and rock, for example, would not be the same (although it is shown as the same in Fig. 4). Mellon et al. (2000) showed that a difference of 0.2 in albedo (between 0.15 and 0.35 ) can result in a difference of $\sim 20$ degrees in the maximum temperature experienced by the material. Hence, the surface temperature variation of each material should be scaled by its albedo to make our temperature model more accurate. In order of decreasing albedo on Mars, we expect dust $>$ fines, $\mathrm{H}_{2} \mathrm{O}$ ice $>$ icy soil $>$ rock.

\section{Appendix D}

Athy (1930) described terrestrial pore space (porosity) as exponentially decreasing with depth due to increasing overburden pressure. Percentage porosity at a depth $z(\mathrm{~m})$ is given by $\phi(z)=\phi_{0} e^{-k z}$, where $\phi_{0}$ is the surface porosity and the rate of decrease depends on the compaction coefficient $k$ $\left(\mathrm{m}^{-1}\right)$. A wide range of porosities are encountered at a given depth in terrestrial materials; however, with increasing depth the maximum porosity decreases (Jamialahmadi and Javadpour, 2000). Fractures filled with brine have been found in terrestrial continental rock at $11 \mathrm{~km}$ (Soviet ultradeep Kola SG3 borehole; Jodicke, 1992), while estimated porosities for crustal rocks at this depth range from $0.5 \%$ to $3 \%$ (Hyndman and Shearer, 1989). The pressures at this depth on Earth are equivalent to $\sim 20 \mathrm{~km}$ on Mars. Porosity at pressures above $100 \mathrm{MPa}$ is generally assumed to be zero (Christensen, 1973); however, modeling of crustal rocks by Abdulagatov et al. (2006) at pressure up to $350 \mathrm{MPa}$ and a range of temperatures revealed porosities around $1 \%$ for amphibole, granulite, and pyroxene granulite rocks. This is consistent with modeled conditions at $\sim 40 \mathrm{~km}$ depth on Mars. Within the terrestrial mantle (deeper than $\sim 40 \mathrm{~km}$; pressures equivalent to $\sim 200 \mathrm{~km}$ on Mars), liquid water takes the form of very small-volume fluid inclusions trapped within mineral crystals. Hyndman and Shearer (1989; and references therein) suggested that pore fluid can potentially exist down to a limiting temperature of $350-400^{\circ} \mathrm{C}$. This temperature limit is not due to the phase space of water but rather to the extreme deformation of pore space in all rocks at this temperature, which restricts the available volume for water. These temperature conditions correspond to $\sim 200 \mathrm{~km}$ depth on Mars from Fig. 1 (and are consistent with the estimate of the deepest water in Fig. 3 from phase space requirements); however, overburden pressure may effectively close pore space before these temperatures are reached. Hence, in summary, pore space in plutonic martian rocks would be expected to fall below $1 \%$ volume at depths greater than $40 \mathrm{~km}$ (less deep in basalts, see Appendix C). No rocks that are deeper than $200 \mathrm{~km}$ or have experienced temperatures of $400^{\circ} \mathrm{C}$ would be expected to have any pore space due to temperature-induced deformation. Liquid water may still be present in hydrated minerals; however, there is no evidence thus far that liquid water in such a state alone can sustain biology.

Permeability is related to porosity in a complex way that is not well known (Rezaee et al., 2006) - permeability decreases with increasing depth in porous media, and the relationship between permeability and porosity is modeled to be a power law (David et al., 1994). However, permeability can also vary widely at a given depth due to mineralogy, fracturing, grain cementation, and so on. (Wang et al., 2009). There is no general analytic function to describe the variation of permeability with depth. Permeability is highly anisotropic and heterogeneous (Saar and Magna, 2004), and in the terrestrial crust it can vary by $10^{5}$ in a particular soil unit. The difference between a low-permeability material such as crystalline rock and a high-permeability material such as well-sorted gravels can be 16 orders of magnitude (Ingebritsen and Manning, 1999). Depth is the strongest control on subsurface permeability; however, it strongly decreases at the brittleductile transition (Ingebritsen and Manning, 1999; 10$15 \mathrm{~km}$ depth on Earth) due to the decreased fracturing and porosity of the rocks at this depth. Below the brittle-ductile transition, permeability is not a strong function of depth. A medium is considered "impermeable" if its permeability is $<10^{-19} \mathrm{~m}^{2}$. This permeability value indicates that it would take $10^{7} \mathrm{~s}\left(\sim 116\right.$ days) for $1 \mathrm{~cm}^{3}$ of gas or liquid (with a viscosity of $1 \mathrm{mPa} \mathrm{s}$, consistent with liquid water at $20^{\circ} \mathrm{C}$ ) to flow through a section of rock $1 \mathrm{~cm}$ thick with a cross section of $1 \mathrm{~cm}^{2}$, when the difference between the pressures on the two sides of the section is $1 \mathrm{~atm}$ (Wyckoff et al., 1933).

The permeability of the crystalline granitic rock of the continental crust is modeled with a power law function of $k=10^{-14} z^{-3.2}\left(k\right.$ in $\mathrm{m}^{2}, z$ in $\mathrm{km}, z \leq 35$; Manning and Ingebritsen, 1999). Saar and Magna (2004) corrected this function by adding an exponential decay function with a half-life 
of $170 \mathrm{~m}$ to better fit permeability shallower than $2 \mathrm{~km}$ (which was overestimated by the power law function). Below the brittle-ductile transition (mean depth of $\sim 12 \mathrm{~km}$ on Earth), the permeability can be equally well modeled by a constant of $10^{-18.5} \mathrm{~m}^{2}$, as it is effectively independent of depth (Manning and Ingebritsen, 1999). Permeability in crystalline rocks is generally through small numbers of interconnected fractures that provide fluid pathways (Huenges et al., 1997). Despite this analytic function for the permeability of the continential crust, measured values and the peremability-depth relationship can be significantly different. A borehole of the German Continental Deep Drilling Program at $9101 \mathrm{~m}$ depth encountered fluid-conducting rock with a permeability of $\sim 10^{-16} \mathrm{~m}^{2}$ at $103 \mathrm{MPa}$ (Huenges et al., 1997), which is in good agreement with the modeled permeability at this depth of $\sim 10^{-17} \mathrm{~m}^{2}$. However, no clear depth dependence of permeability was observed in the granitic rocks in the borehole. From the above permeability function, the continental crust becomes impermeable at $\sim 35 \mathrm{~km}$; however, it is essentially impermeable (modeled permeability of $10^{-18.5} \mathrm{~m}^{2}$ ) at the brittle-ductile transition at a mean depth of $\sim 12 \mathrm{~km}$.

The permeability versus depth function in the oceanic crust (basalt) is modeled from the Costa Rica borehole 504B to be exponential $k=0.11 e^{-z / 50} \times 10^{-12}$ with a half-life of $34 \mathrm{~m}(k$ in $\mathrm{m}^{2}, z$ in $\mathrm{m}$; Anderson et al., 1985). This permeability is due to both connected pore space and fracture porosity. Anderson et al. (1985) showed that maximum permeability at a given depth (large uncertainties in measurement) roughly linearly decreased with increasing depth. It is not known whether the permeability versus depth function is representative of either oceanic crust in other locations or of pillow basalt layers in general. If the function can be extrapolated to greater depths, then the oceanic crust in the region of the borehole becomes impermeable at $\sim 700 \mathrm{~m}$ depth (Anderson et al., 1985).

\section{Acknowledgments}

We thank Chris McKay, Graziella Caprarelli, and other colleagues for useful discussions. We also thank two anonymous reviewers for helping us improve the clarity of this article. Eriita Jones acknowledges funding from an Australian Postgraduate Award and the Research School of Astronomy and Astrophysics (ANU).

\section{Author Disclosure Statement}

No competing financial interests exist for either Eriita G. Jones or Charles H. Lineweaver, or Jonathan D. Clarke.

\section{Abbreviations}

CMB, core-mantle boundary; MSL, Mars Science Laboratory; $\mathrm{P}-\mathrm{T}$, pressure-temperature.

\section{References}

Abdulagatov, I., Emirov, S., Abdulagatova, Z., and Askerov, S. (2006) Effect of pressure and temperature of the thermal conductivity of rocks. J Chem Eng Data 51:22-33.

Abyzov, S., Mitskevich, I., and Poglazova, M. (1998) Microflora of the deep glacier horizons of central Antarctica. Microbiology $67: 451-458$.

Altheide, T., Chevrier, V., Nicholson, C., and Denson, J. (2009) Experimental investigation of the stability and evaporation of sulfate and chloride brines on Mars. Earth Planet Sci Lett 282:69-78.

Amend, J., Meyer-Dombard, D., Sheth, S., Zolotova, N., and Amend, A. (2003) Palaeococcus helgesonii sp. nov., a facultatively anaerobic, hyperthermophilic archaeon from a geothermal well on Vulcano Island, Italy. Arch Microbiol 179:394-401.

Andersen, D., Pollard, W., McKay, C., and Heldmann, J. (2002) Cold springs in permafrost on Earth and Mars. J Geophys Res 107, doi:10.1029/2000JE001436.

Anderson, D. and Tice, A. (1972) Predicting unfrozen water contents in frozen soils from surface area measurements. Highway Research Record 393:12-18.

Anderson, R., Zoback, M., Hickman, S., and Newmark, R. (1985) Permeability versus depth in the upper oceanic crust: in situ measurements in DSDP Hole 504B, eastern equatorial pacific. J Geophys Res 90:3659-3669.

Athy, L. (1930) Density, porosity and compaction of sedimentary rocks. Am Assoc Pet Geol Bull 14:1-24.

Bains, W. (2004) Many chemistries could be used to build living systems. Astrobiology 4:137-167.

Barlow, N. (2008) Mars: An Introduction to Its Interior, Surface and Atmosphere, Cambridge University Press, Cambridge, UK.

Barth, C. (1974) The atmosphere of Mars. Annu Rev Earth Planet Sci 2:337-367.

Beaty, D., Buxbaum, K., Meyer, M., Barlow, N., Boynton, W., Clark, B., Deming, J., Doran, P., Edgett, K., Hancock, S., Head, J., Hecht, M., Hipkin, V., Kieft, T., Mancinelli, R., McDonald, E., McKay, C., Mellon, M., Newsom, H., Ori, G., Paige, D., Schuerger, A., Sogin, M., Spry, A., Steele, A., Tanaka, K., and Voytek, M. (2006) Findings of the Mars Special Regions Science Analysis Group. Astrobiology 6:677-732.

Benner, S., Ricardo, A., and Carrigan, M. (2004) Is there a common chemical model for life in the Universe? Curr Opin Chem Biol 8:672-689.

Bertka, C. and Fei,Y. (1997) Mineralogy of the martian interior up to core-mantle boundary pressures. J Geophys Res 102:5251-5264.

Bibring, J-P., Langevin, Y., Gendrin, A., Gondet, B., Poulet, F., Berthe, M., Soufflot, A., Arvidson, R., Mangold, N., Mustard, J., Drossart, P., and the OMEGA team. (2005) Mars surface diversity as revealed by the OMEGA/Mars Express Observations. Science 307:1576-1581.

Boston, P., Ivanov, M., and McKay, C. (1992) On the possibility of chemosynthetic ecosystems in subsurface habitats on Mars. Icarus 95:300-308.

Bourke, M., Balme, M., Beyer, R., Williams, K., and Zimbelman, J. (2006) A comparison of methods used to estimate the height of sand dunes on Mars. Geomorphology 81:440-452.

Britt, D. and Consolmagno, G. (2003) Stony meteorite porosities and densities: a review of the data through 2001. Meteorit Planet Sci 38:1161-1180.

Carr, M. (2006) The Surface of Mars, Cambridge University Press, Cambridge, UK.

Chevrier, V. and Altheide, T. (2008) Low temperature aqueous ferric sulfate solutions on the surface of Mars. Geophys Res Lett 35, doi:10.1029/2008GL035489.

Chevrier, V., Ulrich, R., and Altheide, T. (2009) Viscosity of liquid ferric sulfate solutions and application to the formation of gullies on Mars. J Geophys Res 114, doi:10.1029/2009JE003376. Chivian, D., Brodie, E., Alm, E., Culley, D., Dehal, P., DeSantis, T., Gihring, T., Lapidus, A., Lin, L-H., Lowry, S., Moser, D., Richardson, P., Southam, G., Wanger, G., Pratt, L., Anderson, G., Hazen, T., Brockman, F., Arkin, A., and Onstott, T. (2008) Environmental genomics reveals a single-species ecosystem deep within Earth. Science 322:275-278. 
Christensen, N. (1973) Compressional and shear wave velocities in basaltic rocks, deep sea drilling project, leg 16. In Deep Sea Drilling Project Initial Reports, Vol. 16, Ocean Drilling Program, College Station, TX, pp 647-649.

Christensen, P. (1986) Regional dust deposits on Mars: physical properties, age and history. J Geophys Res 91:3533-3545.

Christensen, P. (2003) Formation of recent martian gullies through melting of extensive water-rich snow deposits. Nature 422:45-48.

Chyba, C., Clifford, S., Delamere, A., Favero, M., Mathur, E., Niehoff, J., Ori, G., Paige, D., Pearson, A., Priscu, J., Race, M., Sogin, M., and Takacs-Vesbach, C. (2006) Preventing the forward Contamination of Mars, The National Academies Press, Washington DC.

Clauser, C. and Huenges, E. (1995) Thermal conductivity of rocks and minerals. In Rock Physics and Phase Relations: A Handbook of Physical Constants, edited by T. Ahrens, American Geophysical Union, Washington DC, pp 105-126.

Clifford, S. (1987) Mars: crustal pore volume, cryospheric depth, and the global occurrence of groundwater. In MECA Symposium on Mars: Evolution of its Climate and Atmosphere, LPI Technical Report Number 87-01, Lunar and Planetary Institute, Houston, pp 32-34.

Connolly, J. and Khan, A. (2006) Constraining composition and thermal state of Mars from inversion of geophysical data [abstract \#P31C-0148]. In American Geophysical Union, Fall Meeting 2006, American Geophysical Union, Washington DC.

Conrath, B.J., Pearl, J.C., Smith, M.D., Maguire, W.C., Christensen, P.R., Dason, S., and Kaelberer, M.S. (2000) Mars Global Surveyor Thermal Emission Spectrometer (TES) observations: atmospheric temperatures during aerobraking and science phasing. J Geophys Res 105:9509-9519.

David, C., Wong, T., Zhu, W., and Zhang, J. (1994) Laboratory measurement of compaction-induced permeability change in porous rocks: implications for the generation and maintenance of pore pressure excess in the crust. Pure and Applied Geophysics 143:425-456.

Davila, A., Gómez-Silva, B., de los Rios, A., Ascaso, C., Olivares, H., McKay, C., and Wierzchos, J. (2008) Facilitation of endolithic microbial survival in the hyperarid core of the Atacama Desert by mineral deliquescence. J Geophys Res 113:1-9.

Davis, N. (2001) Permafrost: A Guide to Frozen Ground in Transition, University of Alaska Press, Fairbanks, AL.

de Vera, J., Möhlmann, D., Butina, F., Lorek, A., Wernecke, R., and Ott, S. (2010) Survival potential and photosynthetic activity of lichens under Mars-like conditions: a laboratory study. Astrobiology 10:215-227.

Fei, Y. and Bertka, C. (2005) The interior of Mars. Science 308:1120-1121.

Fennema, O. (1996) Food Chemistry, CRC Press, Boca Raton, FL.

Folkner, W., Yoder, C., Yuan, D., Standish, E., and Preston, R. (1997) Interior structure and seasonal mass redistribution of Mars from radio tracking of Mars Pathfinder. Science 278:1749-1752.

Gangwar, P., Alam, S., Bansod, S., and Singh, L. (2009) Can J Microbiol 55:564-577.

Gendrin, A., Mangold, N., Bibring, J-P., Langevin, Y., Gondet, B., Poulet, F., Bonello, G., Quantin, C., Mustard, J., Arvidson, R., and LeMouelic, S. (2005) Sulfates in martian layered terrains: the OMEGA/Mars Express view. Science 307:1587-1591.

Gold, T. (1992) The deep, hot biosphere. Proc Natl Acad Sci USA 89:6045-6049.

Golombek, M., Grant, J., Vasavada, A.R., Grotzinger, J., Watkins, M., Kipp, D., Noe Dobrea, E., Griffes, J., and Parker, T. (2011)
Final four landing sites for the Mars Science Laboratory [abstract 1520]. In $42^{\text {nd }}$ Lunar and Planetary Science Conference, Lunar and Planetary Institute, Houston.

Grant, W. (2004) Life at low water activity. Philos Trans R Soc Lond B Biol Sci 359:1249-1267.

Griffin, D. (2008) Non-spore forming eubacteria isolated at an altitude of 20,000 m in Earth's atmosphere: extended incubation periods needed for culture based assays. Aerobiologia 24:19-25.

Gudkova,T. and Zharkov,V. (2004) Mars: interior structure and excitation of free oscillations. Physics of the Earth and Planetary Interiors 142:1-22.

Guidry, S. and Chafetz, H. (2003) Anatomy of siliceous hot springs: examples from Yellowstone National Park, Wyoming, USA. Sediment Geol 157:71-106.

Gunde-Cimerman, N., Sonjak, S., Zalar, P., Frisvad, J., Diderichsen, B., and Plemenitas, A. (2003) Extremophilic fungi in Arctic ice: a relationship between adaptation to low temperature and water activity. Phys Chem Earth 28:1273-1278.

Haberle, R., McKay, C., Schaeffer, J., Cabrol, N., Grin, E., Zent, A., and Quinn, R. (2001) On the possibility of liquid water on present-day Mars. J Geophys Res 106:23317-23326.

Hahn, B. and McLennan, S. (2008) Martian surface heat production and crustal heat flow from Mars Odyssey gamma-ray spectrometry [abstract 2032]. In $39^{\text {th }}$ Lunar and Planetary Science Conference, Lunar and Planetary Institute, Houston.

Heard, J., Kladivko, E., and Mannering, J. (1988) Soil macroporosity, hydraulic conductivity and air permeability of silty soils under long-term conservation tillage in Indiana. Soil and Tillage Research 11:1-18.

Hecht, M. (2002) Metastability of liquid water on Mars. Icarus 156:373-386.

Heldmann, J. and Mellon, M. (2004) Observations of martian gullies and constraints on potential formation mechanisms. Icarus 168:285-304.

Heldmann, J., Toon, O., Pollard, W., Mellon, M., Pitlick, J., McKay, C., and Andersen, D. (2005) Formation of martian gullies by the action of liquid water flowing under current martian environmental conditions. J Geophys Res 110, doi:10.1029/2004JE002261.

Heldmann, J., Carlsson, E., Johansson, H., Mellon, M., and Toon, O. (2007) Observations of martian gullies and constraints on potential formation mechanisms II: the northern hemisphere. Icarus 188:324-344.

Hewitt, C. and Jackson, A. (2003) Handbook of Atmospheric Science-Principles and Applications, Wiley-Blackwell Publishers, New York.

Hinson, D., Smith, M., and Conrath, B. (2004) Comparison of atmospheric temperatures obtained through infrared sounding and radio occultation by Mars Global Surveyor. J Geophys Res 109, doi:10.1029/2004JE002344.

Hoffman, N. (2000) White Mars: a new model for Mars' surface and atmosphere based on $\mathrm{CO}_{2}$. Icarus 146:326-342.

Horneck, G. (2000) The microbial world and the case for Mars. Planet Space Sci 48:1053-1063.

Horneck, G. (2008) The microbial case for Mars and its implication for human expeditions to Mars. Acta Astronaut 63:10151025.

Houtkooper, J. and Schulze-Makuch, D. (2007) A possible biogenic origin for hydrogen peroxide on Mars: the Viking results reinterpreted. International Journal of Astrobiology 6:147-152.

Hubbard, G., Naderi, F., and Garvin, J. (2002) Following the water, the new program for Mars exploration. Acta Astronaut 51:337-350. 
Hudson, T. and Aharonson, O. (2008) Diffusion barriers at Mars surface conditions: salt crusts, particle size mixtures, and dust. J Geophys Res 113, doi:10.1029/2007JE003026.

Huenges, E., Erzinger, J., and Kuck, J. (1997) The permeable crust: geohydraulic properties down to $9101 \mathrm{~m}$ depth. J Geophys Res 102:18255-18265.

Hyndman, R. and Shearer, P. (1989) Water in the lower continental crust: modelling magnetotelluric and seismic reflection results. Geophysical Journal International 98:343-365.

Hyne, N. (2001) Nontechnical Guide to Petroleum Geology, Exploration, Drilling and Production, PennWell Books, Tulsa, OK.

Ingebritsen, S. and Manning, C. (1999) Geological implications of a permeability-depth curve for the continental crust. Geology 27:1107-1110.

Irwin, L. and Schulze-Makuch, D. (2001) Assessing the plausibility of life on other worlds. Astrobiology 1:143-160.

Imshenetsky, A., Lysenko, S., and Kazakov, G. (1978) Upper boundary of the biosphere. Appl Environ Microbiol 35:1-5.

Jagoutz, E. (2006) Salt-induced rock fragmentation on Mars: the role of salt in the weathering of martian rocks. Adv Space Res 38:696-700.

Jakosky, B., Nealson, K., Bakermans, C., Ley, R., and Mellon, M. (2003) Subfreezing activity of microorganisms and the potential habitability of Mars' polar regions. Astrobiology 3:343352.

Jakosky, B., Mellon, M., Varnes, E., Feldman, W., Boynton, W., and Haberle, R. (2005a) Mars low-latitude neutron distribution: possible remnant near-surface water ice and a mechanism for its recent emplacement. Icarus 175:58-67.

Jakosky, B., Mellon, M., Varnes, E., Feldman, W., Boynton, W., and Haberle, R. (2005b) Erratum to: Mars low-latitude neutron distribution: possible remnant near-surface water ice and a mechanism for its recent emplacement. Icarus 178:291-293.

James, D. (1968) The thermal diffusivity of ice and water between -40 and $+60^{\circ} \mathrm{C}$. Journal of Materials Science 3:540543.

Jamialahmadi, M. and Javadpour, F. (2000) Relationship of permeability, porosity and depth using an artificial neural network. Journal of Petroleum Science and Engineering 26:235-239.

Jepsen, S., Priscu, J., Grimm, R., and Bullock, M. (2007) The potential for lithoautotrophic life on Mars: application to shallow interfacial water environments. Astrobiology 7:342-354.

Jodicke, H. (1992) Water and graphite in the Earth's crust-an approach to interpretation of conductivity models. Surveys in Geophysics 13:381-407.

Jones, E. and Lineweaver, C. (2010) To what extent does terrestrial life "follow the water"? Astrobiology 10:349-361.

Jones, E. and Lineweaver, C. (2011) Using the phase diagram of liquid water to search for life. Australian Journal of Earth Sciences, in press.

Junge, K., Eicken, H., and Deming, J. (2004) Bacterial activity at -2 to $-20^{\circ} \mathrm{C}$ in Arctic wintertime sea ice. Appl Environ Microbiol 70:550-557.

Kashefi, K.M. and Lovley, D. (2003) Extending the upper temperature limit for life. Science 301:934.

Kieffer, H., Martin, T., Peterfreund, A., Jakosky, B., Miner, E., and Palluconi, F. (1977) Thermal and albedo mapping of Mars during the Viking primary mission. J Geophys Res 82:42494291.

Koop, T. (2004) Homogenous ice nucleation in water and aqueous solutions. Z Phys Chem 218:1231-1258.

Koop, T., Luo, B., Tsias, A., and Peter, T. (2000) Water activity as the determinant for homogenous ice nucleation in aqueous solutions. Nature 406:611-614.
Landis, G. (2001) Martian water: are their extant halobacteria on Mars? Astrobiology 1:161-164.

Langdahl, B. and Ingvorsen, K. (1997) Temperature characteristics of bacterial iron solubilisation and ${ }^{14} \mathrm{C}$ assimilation in naturally exposed sulfide ore material at Citronen Fjord, North Greenland $\left(83^{\circ} \mathrm{N}\right)$. FEMS Microbiol Ecol 23:275-283.

Lee, C. and Farmer, I. (1990) A simple method of estimating rock mass porosity and permeability. Geotechnical and Geological Engineering 8:57-65.

Litvak, M., Mitrofanov, I., Barmakov, Y., Behar, A., Bitulev, A., Bobrovnitsky, Y., Bogolubov, E., Boynton, W., Bragin, S., Churin, S., Grebennikov, A., Konovalov, A., Kozyrev, A., Kurdumov, I., Krylov, A., Kuznetsov, Y., Malakhov, A., Mokrousov, M., Ryzhkov, V., Sanin, A., Shvetsov, V., Smirnov, G., Sholeninov, S., Timoshenko, G., Tomilina, T., Tuvakin, D., Tretyakov, V., Troshin, V., Uvarov, V., Varenikov, A., and Vostrukhin, A. (2008) The dynamic albedo of neutrons (DAN) experiment for NASA's 2009 Mars Science Laboratory. Astrobiology 8:605-612.

Lodders, K. and Fegley, B. (1998) The Planetary Scientist's Companion, Oxford University Press, Oxford.

Longhi, J., Knittle, E., Holloway, J., and Waenke, H. (1992) The bulk composition, mineralogy and internal structure of mars. In Mars, edited by H. Kieffer, University of Arizona Press, Tuscon, AZ, pp 184-208.

Mancinelli, R., Fahlen, T., Landheim, R., and Klovstad, M. (2004) Brines and evaporates: analogs for martian life. Adv Space Res 33:1244-1246.

Manning, C. and Ingebritsen, S. (1999) Permeability of the continental crust: implications of geothermal data and metamorphic systems. Rev Geophys 37:127-150.

Mariana Trench. (2003) The Mariana Trench—biology. Available online at http://www.marianatrench.com/mariana_trenchbiology_001.htm.

Marion, G., Catling, D., and Kargel, J. (2009) Br/Cl partitioning in chloride minerals in the Burns Formation on Mars. Icarus 200:436-445.

Marion, G., Catling, D., Zahnle, K., and Claire, M. (2010) Modelling aqueous perchlorate chemistries with applications to Mars. Icarus 207:675-685.

Marquez, A., Angel de Pablo, M., Oyarzun, R., and Viedma, C. (2005) Evidence of gully formation by regional groundwater flow in the Gorgonum-Newton region (Mars). Icarus 179:398414.

Martin, W., Baross, J., Kelley, D., and Russell, M. (2008) Hydrothermal vents and the origin of life. Nat Rev Microbiol 6:805-815.

Mazur, P. (1980) Limits to life at low temperatures and at reduced water contents and water activities. Orig Life 10:137159.

McCleese, D., Farmer, J., Des Marais, D., Jakosky, B., Kocurek, G., Ming, D., Mahaffy, P., McLennan, S., Paige, D., Taylor, J., and Waite, H. (2003) Mars Science Laboratory Project Science Integration Group final report. Project Science Integration Group (PSIG), Mars Exploration Program Analysis Group.

McGovern, P., Solomon, S., Smith, D., Zuber, M., Simons, M., Wieczorek, M., Phillips, R., Neumann, G., Aharonson, O., and Head, J. (2002) Localized gravity/topography admittance and correlation spectra on Mars: implications for regional and global evolution. J Geophys Res 107, doi:10.1029/2002JE001854.

McGovern, P., Solomon, S., Smith, D., Zuber, M., Simons, M., Wieczorek, M., Phillips, R., Neumann, G., Aharonson, O., and Head, J. (2004) Correction to "Localized gravity/topography admittance and correlation spectra on Mars: implications for 
regional and global evolution". J Geophys Res 109, doi:10.1029/ 2004JE002286.

McKenzie, D., Barnett, D., and Yuan, D. (2002) The relationship between martian gravity and topography. Earth Planet Sci Lett 195:1-16.

Mellon, M. (1996) Limits on the $\mathrm{CO}_{2}$ content of the martian polar deposits. Icarus 124:268-279.

Mellon, B., Jakosky, B., Kieffer, H.H., and Christensen, P.R. (2000) High-resolution thermal inertia mapping from the Mars Global Surveyor Thermal Emission Spectrometer. Icarus 148:437-455.

Mellon, M. (2001) Thermal inertia and rock abundance. In Exploring Mars with TES: a Data User's Workshop, November 1315, Arizona State University, Tempe, AZ, pp 1-6.

Mellon, M. and Phillips, R. (2001) Recent gullies on Mars and the source of liquid water. J Geophys Res 106:1-15.

Mellon, M., Feldman, W., and Prettyman, T. (2004) The presence and stability of ground ice in the southern hemisphere of Mars. Icarus 169:324-340.

Milliken, R., Mustard, J., Poulet, F., Jouglet, D., Bibring, J-P., Gondet, B., and Langevin, Y. (2007) Hydration state of the martian surface as seen by Mars Express OMEGA: 2. $\mathrm{H}_{2} \mathrm{O}$ content of the surface. J Geophys Res 112, doi:10.1029/ 2006JE002853.

Möhlmann, D. (2004) Water in the upper martian surface at midand low-latitudes: presence, state, and consequences. Icarus 168:318-323.

Möhlmann, D. (2005) Adsorption water-related potential chemical and biological processes in the upper martian surface. Astrobiology 5:770-777.

Möhlmann, D. (2008) The influence of van der Waals forces on the state of water in the shallow subsurface of Mars. Icarus 195:131-139.

Möhlmann, D. (2010a) The three types of liquid water in the surface of present Mars. International Journal of Astrobiology 9:45-49.

Möhlmann, D. (2010b) Temporary liquid water in the upper snow/ice sub-surfaces of Mars. Icarus 207:140-148.

Morillon, V., Debeaufort, F., Jose, J., Tharrault, J., Capelle, M., Blond, G., and Voilley, A. (1999) Water vapor pressure above saturated salt solutions at low temperatures. Fluid Phase Equilib 155:297-309.

Morozov, D., Möhlmann, D., and Wagner, D. (2007) Survival of methanogenic archaea from Siberian permafrost under simulated martian thermal conditions. Orig Life Evol Biosph 37:189200.

Murphy, N., Jakosky, B., Mellon, M., and Budd, D. (2009) Thermophysical properties of martian duricrust analogs [abstract 1420]. In $40^{\text {th }}$ Lunar and Planetary Science Conference, Lunar and Planetary Institute, Houston.

Nelli, S., Renno, N., Murphy, J., and Feldman, W. (2009) Simulations of atmospheric processes at the Phoenix landing site with the Ames GCM [abstract \#44.05]. In 41 ${ }^{\text {st }}$ Annual Meeting of the Division for Planetary Sciences of the American Astronomical Society, American Astronomical Society, Washington DC.

Neumann, G., Zuber, M., Wieczorek, M., McGovern, P., Lemoine, F., and Smith, D. (2004) Crustal structure of Mars from gravity and topography. J Geophys Res 109, doi:10.1029/ 2004JE002262.

Papuc, A. and Davies, G. (2008) The internal activity and thermal evolution of Earth-like planets. Icarus 195:447-458.

Pavlov, A., Shelegedin, V., Vdovina, M., and Pavlov, A. (2010) Growth of microorganisms in martian-like shallow subsurface conditions: laboratory modelling. International Journal of Astrobiology 9:51-58.

Pearson, N. and Derbyshire, W. (1974) NMR studies of water absorbed on a number of silica surfaces. J Colloid Interface Sci 46:232-248.

Pedersen, K. (1993) The deep subterranean biosphere. EarthScience Reviews 34:243-260.

Pedersen, K. (2000) Exploration of deep intraterrestrial microbial life: current perspectives. FEMS Microbiol Lett 185:9-16.

Piqueux, S. and Christensen, P. (2009) A model of thermal conductivity for planetary soils: 2 . Theory for cemented soils. J Geophys Res 114, doi:10.1029/2008JE003309.

Pollack, H. and Huang, S. (2000) Climate reconstruction from subsurface temperatures. Annu Rev Earth Planet Sci 28:339-365.

Price, P. (2000) A habitat for psychrophiles in deep Antarctic ice. Proc Natl Acad Sci USA 97:1247-1251.

Price, P. and Sowers, T. (2004) Temperature dependence of metabolic rates for microbial growth, maintenance, and survival. Proc Natl Acad Sci USA 101:4631-4636.

Prol-Ledesma, R. (2003) Similarities in the chemistry of shallow submarine hydrothermal vents. Geothermics 32:639-644.

Renno, N., Bos, B., Catling, D., Clark, B., Drube, L., Fisher, D., Goetz, W., Hviid, S., Keller, H., Kok, J., Kounaves, S., Leer, K., Lemmon, M., Madsen, M., Markiewicz, W., Marshall, J., McKay, C., Mehta, M., Smith, M., Zorzano, M., Smith, P., Stoker, C., and Young, S. (2009) Possible physical and thermodynamical evidence for liquid water at the Phoenix landing site. J Geophys Res 114, doi:10.1029/2009JE003362.

Rezaee, M., Jafari, A., and Kazemzadeh, E. (2006) Relationships between permeability, porosity and pore throat size in carbonate rocks using regression analysis and neural networks. Journal of Geophysics and Engineering 3:370-376.

Rivkina, E., Friedmann, E., McKay, C., and Gilichinksky, D. (2000) Metabolic activity of permafrost bacteria below the freezing point. Appl Envron Microbiol 66:3230-3233.

Saar, M. and Magna, M. (2004) Depth dependence of permeability in the Oregon Cascades inferred from hydrogeologic, thermal, seismic, and magmatic modelling constraints. J Geophys Res 109, doi:10.1029/2003JB002855.

Schrenk, M., Kelley, D., Delaney, J., and Baross, J. (2003) Incidence and diversity of microorganisms within the walls of an active deep-sea sulfide chimney. App Environ Microbiol 69:3580-3592.

Schulze-Makuch, D. and Houtkooper, J. (2010) A perchlorate strategy for extreme xerophilic life on Mars? EPSC Abstracts 5, EPSC2010-308.

Schulze-Makuch, D. and Irwin, L. (2006) The prospect of alien life in exotic forms on other worlds. Naturwissenschaften 93:155-172.

Schulze-Makuch, D. and Irwin, L. (2008) Life in the Universe: Expectations and Constraints, Springer-Verlag, Berlin.

Schulze-Makuch, D., Haque, S., de Sousa Antonio, M., Ali, D., Hosein, R., Song, Y., Yang, J., Zaikova, E., Beckles, D., Guinan, E., Lehto, H., and Hallam, S. (2011) Microbial life in a liquid asphalt desert. Astrobiology 11:241-258.

Sears, D. and Moore, S. (2005) On laboratory simulation and the evaporation rate of water on Mars. Geophys Res Lett 32, doi:10.1029/2005GL023443.

Sherwood Lollar, B., Moran, J., Tille, S., Voglesonger, K., Lacrampe-Couloume, G., Onstott, T., Pratt, L., and Slater, G. (2009) Hydrogeologic controls on the deep terrestrial biosphere-chemolithotrophic energy for subsurface life on Earth and Mars [abstract \# B24A-01]. In 2009 Joint Assembly, American Geophysical Union, Washington DC. 
Sizemore, H. and Mellon, M. (2006) Effects of soil heterogeneity on martian ground-ice stability and orbital estimates of ice table depth. Icarus 185:358-369.

Smith, M., Wolff, M., Spanovich, N., Ghosh, A., Banfield, D., Christensen, P., Landis, G., and Squyres, S. (2006) One martian year of atmospheric observations using MER mini-TES. J Geophys Res 111:12.

Sohl, F. and Spohn, T. (1997) The interior structure of Mars: implications from SNC meteorites. J Geophys Res 102:16131635.

Sohl, F., Schubert, G., and Spohn, T. (2005) Geophysical constraints on the composition and structure of the martian interior. J Geophys Res 110, doi:10.1029/2005JE002520.

Solomon, S. and Head, J. (1990) Heterogeneities in the thickness of the elastic lithosphere of Mars-constraints on heat flow and internal dynamics. J Geophys Res 95:11073-11083.

Stetter, K. (2006) History of discovery of the first hyperthermophiles. Extremophiles 10:357-362.

Stüwe, K. (2007) Geodynamics of the Lithosphere: An Introduction, Springer Verlag, Berlin.

Szewzyk, U. and Szewzyk, R. (1994) Thermophillic, anaerobic bacteria isolated from a deep borehole in granite in Sweden. Proc Natl Acad Sci USA 91:1810-1813.

Takai, K., Nakamura, K., Toki, T., Tsunogai, U., Miyazaki, M., Miyazaki, J., Hirayama, H., Nakagawa, S., Nunoura, T., and Horikoshi, K. (2008) Cell proliferation at $122^{\circ} \mathrm{C}$ and isotopically heavy $\mathrm{CH}_{4}$ production by a hyperthermophilic methanogen under high-pressure cultivation. Proc Natl Acad Sci USA 105:10949-10954.

Takami, H., Inoue, A., Fuji, F., and Horikoshi, K. (1997) Microbial flora in the deepest sea mud of the Mariana trench. FEMS Microbiol Lett 152:279-285.

Titus, T., Kieffer, H., and Christensen, P. (2003) Exposed water ice discovered near the south pole of Mars. Science 299:1048-1051.

Todo, Y., Kitazoto, H., Hashimoto, J., and Gooday, A. (2005) Simple foraminifera flourish at the ocean's deepest point. Science 307:689.

Toksöz, M and Hsui, A. (1978) Thermal history and evolution of Mars. Icarus 34:537-547.

Tosca, N., Knoll, A., and McLennan, S. (2008) Water activity and the challenge for life on early Mars. Science 320:1204-1207.

Turcotte, D. and Schubert, G. (1982) Geodynamics: Applications of Continuum Physics to Geological Problems, John Wiley \& Sons, New York.

Turcotte, D., Shcherbakov, R., Malamud, B., and Kucinskas, A. (2002) Is the martian crust also the martian elastic lithosphere? J Geophys Res 107, doi:10.1029/2001JE001594.

Urquhart, M. and Gulick, V. (2002) Heat flow, thermal conductivity, and the plausibility of the "white Mars" hypothesis [abstract 1680]. In 33 $3^{\text {rd }}$ Lunar and Planetary Science Conference, Lunar and Planetary Institute, Houston.

Vaniman, D., Bish, D., Chipera, S., Fialips, C., Carey, J., and Feldman, W. (2004) Magnesium sulphate salts and the history of water on Mars. Nature 431:663-665.

Verhoeven, O., Rivoldini, A., Vacher, P., Mocquet, A., Choblet, G., Menvielle, M., Dehant, V., Van Hoolst, T., Sleewaegen, J., Barriot, J., and Lognonné, P. (2005) Interior structure of terrestrial planets: modelling Mars' mantle and its electromag- netic, geodetic and seismic properties. J Geophys Res 110, doi:10.1029/2004JE002271.

Wainwright, M., Narlikar, J., and Rajaratnam, P. (2002) Microorganisms cultured from stratospheric air samples obtained at $41 \mathrm{~km}$. FEMS Microbiol Lett 10778:1-5.

Wang, A., Freeman, J., Bell, J., and Jolliff, B. (2010) Potential habitable zone within the subsurface of equatorial regions on Mars [abstract 5400]. In Astrobiology Science Conference 2010: Evolution and Life: Surviving Catastrophes and Extremes on Earth and Beyond, Lunar and Planetary Institute, Houston.

Wang, X-S., Jiang, X-W., Wan, L., Song, G., and Xia, Q. (2009) Evaluation of depth-dependant porosity and bulk modulus of a shear using permeability-depth trends. International Journal of Rock Mechanics and Mining Sciences 46:1175-1181.

Wieczorek, M. and Zuber, M. (2004) Thickness of the martian crust: improved constraints from geoid-to-topography ratios. J Geophys Res 109, doi:10.1029/2003JE002153.

Wierzchos, J., Cámara, B., de Los Ríos, A., Davila, A., Sánchez Almazo, I., Artieda, O., Wierzchos, K., Gomez-Silva, B., McKay, C., and Ascaso, C. (2011) Microbial colonization of Ca-sulfate crusts in the hyperarid core of the Atacama Desert: implications for the search for life on Mars. Geobiology 9:44-60.

Wyckoff, R., Botset, H., Muskat, M., and Reed, D. (1933) The measurement of the permeability of porous media for homogeneous fluids. Rev Sci Instrum 4, doi:10.1063/1.1749155.

Yen, A.S., Gellert, R., Schröder, C., Morris, R.V., Bell, J.F., III, Knudson, A.T., Clark, B.C., Ming, D.W., Crisp, J.A., Arvidson, R.E., Blaney, D., Brückner, J., Christensen, P.R., Des Marais, D.J., de Souza, P.A., Jr., Economou, T.E., Ghosh, A., Hahn, B.C., Herkenhoff, K.E., Haskin, L.A., Hurowitz, J.A., Joliff, B.L., Johnson, J.R., Klingelhöfer, G., Madsen, M.B., McLennan, S.M., McSween, H.Y., Richter, L., Rieder, R., Rodionov, D., Soderblom, L., Squyres, S.W., Tosca, N.J., Wang, A., Wyatt, M., and Zipfel, J. (2005) An integrated view of the chemistry and mineralogy of martian soils. Nature 436:49-54.

Zuber, M. (2001) The crust and mantle of Mars. Nature 412:220227.

Zuber, M., Solomon, S., Phillips, R., Smith, D., Tyler, L., Aharonson, O., Balmino, G., Banerdt, B., Head, J., Johnson, C., Lemoine, F., McGovern, P., Neumann, G., Rowlands, D., and Zhong, S. (2000) Internal structure and early thermal evolution of Mars from Mars Global Surveyor topography and gravity. Science 287:1788-1793.

Address correspondence to: Eriita G. Jones Mount Stromlo Observatory Cotter Road Weston ACT 2611 Australia

E-mail: eriita@mso.anu.edu.au

Submitted 29 March 2011 Accepted 13 September 2011 